Florida International University FIU Digital Commons

$7-3-2013$

\title{
Examining Gradients in Novelty: Native and Non- native Fish Assemblages in Everglades Canals
}

David A. Gandy

Earth and Environment Department, Southeast Environmental Research Center, Florida International University

DOI: $10.25148 /$ etd.FI13080719

Follow this and additional works at: https:// digitalcommons.fiu.edu/etd

Part of the Aquaculture and Fisheries Commons, Biodiversity Commons, and the Terrestrial and Aquatic Ecology Commons

\section{Recommended Citation}

Gandy, David A., "Examining Gradients in Novelty: Native and Non-native Fish Assemblages in Everglades Canals" (2013). FIU Electronic Theses and Dissertations. 951.

https://digitalcommons.fiu.edu/etd/951 


\title{
FLORIDA INTERNATIONAL UNIVERSITY
}

Miami, Florida

\section{EXAMINING GRADIENTS IN NOVELTY: NATIVE AND NON-NATIVE FISH ASSEMBLAGES IN EVERGLADES CANALS}

\author{
A thesis submitted in partial fulfillment of \\ the requirements for the degree of \\ MASTER OF SCIENCE \\ in \\ ENVIRONMENTAL STUDIES \\ by \\ David A. Gandy
}


To: Dean Kenneth G. Furton

College of Arts and Sciences

This thesis, written by David A. Gandy, and entitled Examining Gradients in Novelty: Native and Non-native Fish Assemblages in Everglades Canals, having been approved in respect to style and intellectual content, is referred to you for judgment.

We have read this thesis and recommend that it be approved.

Joel T. Heinen

Hong Liu

Joseph J. Parkos III

Jennifer S. Rehage, Major Professor

Date of Defense: July 3, 2013

The thesis of David A. Gandy is approved.

\begin{tabular}{r}
\hline $\begin{array}{c}\text { Dean Kenneth G. Furton } \\
\text { College of Arts and Sciences }\end{array}$ \\
\hline Dean Lakshmi N. Reddi \\
University Graduate School
\end{tabular}

Florida International University, 2013 
(C) Copyright 2013 by David A. Gandy

All rights reserved. 


\section{DEDICATION}

My graduate thesis work is dedicated to a great man that unconditionally devoted his life to his family- my father, David Charles Gandy (1959-2008). 


\section{ACKNOWLEDGMENTS}

I wish to thank my advisor, Dr. Jennifer Rehage, for providing great support and guidance to me. The mentoring and enthusiasm she provided constantly pushed me intellectually, and shaped me into a better scientist that has prepared me well for future professional and academic endeavors. I would like to thank members of my committee, Joseph Parkos, Hong Liu and Joel Heinen for their support and advice along the way.

Thanks to Jeff Kline and Zach Fratto with Everglades National Park as well as Kevin Whelan, Raul Urgelles, and the rest of the National Park Service South Florida and Caribbean Network crew for all their support and contributions to this study. Thanks to Kevin Kotun with NPS for his help in understanding how canals function hydrologically. A special thanks to all current and past members of Dr. Jennifer Rehage's lab including Ross Boucek, Jessica Lee, Vanessa Trujillo, Jesse Blanchard, Christopher Edwards, Lauren Barth, Diana Lopez, Brett Gallagher, Gareth Blakemore, Amy Narducci, Brett Feger, Juan Pablo Perea, Andrew Jungman, Melissa Anderson, Christine Beck, Clarence Henry, and Oliver Ljustina for devoting many hours of time and effort that made all sampling for this project possible.

My project has been made possible thanks to funding provided by the National Parks Service's Critical Ecosystems Studies initiative (CESI; project \# J5298-10-0011). I also thank the Everglades Foundation Scholarship and the Christina Menendez fellowship through Florida International University's Southeast Environmental Research Center for addition leveraged support. Lastly, I would like to thank my Mother, Terry Gandy, my brother, Mathew Gandy, my girlfriend, Sylvia Lee, and the rest of my family for their constant support, love and encouragement. 


\title{
ABSTRACT OF THE THESIS \\ EXAMINING GRADIENTS IN NOVELTY: NATIVE AND NON-NATIVE FISH ASSEMBLAGES IN EVERGLADES CANALS
}

\author{
By \\ David A. Gandy \\ Florida International University, 2013 \\ Miami, Florida

\section{Professor Jennifer S. Rehage, Major Professor}

Novel ecosystems emerge from alterations to historic abiotic regimes and contain new species combinations. Everglades canals offer an opportunity to understand the function of novel habitat for native and non-native fishes and how novel conditions in turn influence distribution, abundance and assembly patterns. I examined native and nonnative fish assemblages collected across a gradient in novelty, defined by the loss of wetland connectivity and habitat complexity. As novelty increased, native species richness and abundance strongly declined, and the contribution of non-natives increased. Community structure vastly differed among canals and was strongly influenced by spatial factors and secondarily by hydrological factors. Natives and non-natives had opposing responses to key hydrologic and habitat parameters. This study represents the first comprehensive assessment of Everglades canal fishes, providing insight into the factors influencing native and non-native abundance and assembly patterns and contributing to our understanding of this novel but permanent habitat. 


\section{TABLE OF CONTENTS}

CHAPTER

PAGE

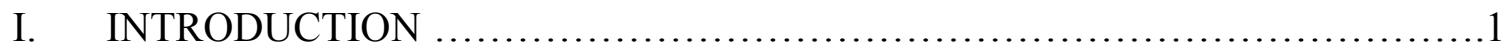

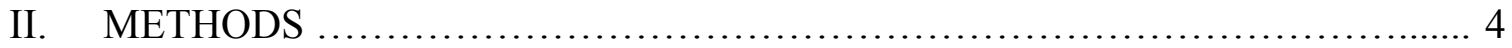

Everglades canals and novelty gradient ................................... 4

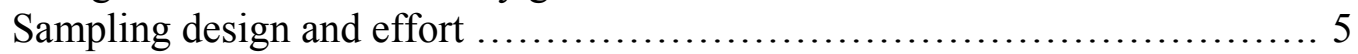

Habitat complexity, abiotic and hydrologic conditions ....................... 7

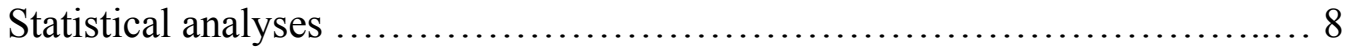

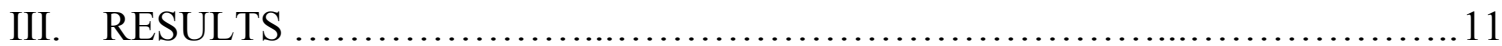

Spatiotemporal variation in habitat and abiotic conditions .................. 11

Spatiotemporal variation in catch per unit effort and richness ............... 12

Relative contribution of non-native versus native taxa ....................... 14

Spatial and seasonal community structure ….............................. 15

Relative contribution of predictor variable sets ............................ 15

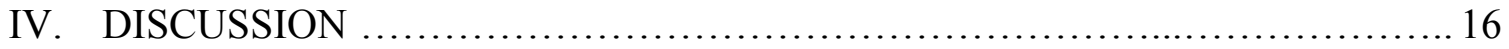

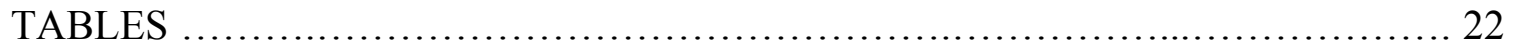

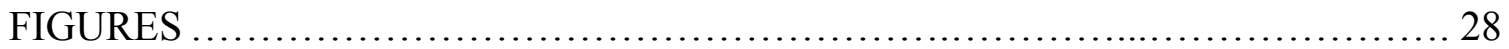

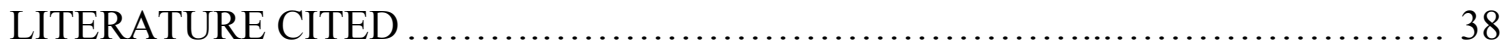

APPENDICES ........................................................................ 46 


\section{LIST OF TABLES}

TABLE

PAGE

1. Number of sample stations and connectivity to marshes for each canal unit 22

2. Description of predictor variables ............................................. 23

3. Factorial ANOVA results for habitat and abiotic variables ........................ 24

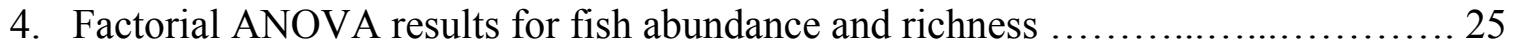

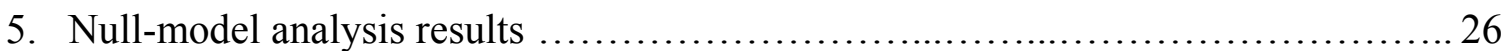

6. Results of distance-based linear models (DISTLM) .......................... 27 


\section{LIST OF FIGURES}

FIGURE

PAGE

1. Hypothesized relationships between native, and non-native fish abundance and richness with increasing novelty in Everglades canals ......................... 28

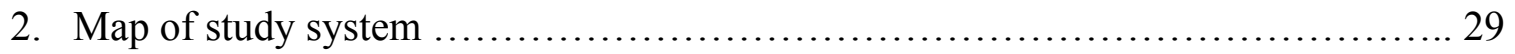

3. Littoral zone habitat characteristics across canal type and season ................. 30

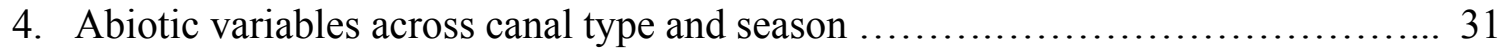

5. Abundance and richness for all fishes, natives and non-natives by canal type .......32

6. Abundance and richness of natives and non-natives across canal type and season ... 33

7. Relative contribution of native versus non-native taxa across canal type for each season .................................................................. 34

8. Non-metric multidimensional scaling (NMDS) ordination illustrating variation in fish community structure across canal types and season ........................ 35

9. Distance based redundancy analyses (dbRDA) model results illustrating the relationship between predictor variables and fish community structure 36

10. Best fit regression models illustrating the relationship between abundance and key hydrologic and habitat variables for native versus non-native taxa ................ 37 


\section{INTRODUCTION}

The synergistic effects of anthropogenic disturbance and species invasions can rapidly alter both ecosystem structure and function (Milton 2003; Root and Schneider 2006; Didham et al. 2007). These effects can result in the alteration of modern day ecosystems to those that share little to no resemblance to their natural counterparts (Fox 2007). Such systems have recently generated much discussion and are often referred to as 'no-analog' or 'novel' ecosystems (Milton 2003; Fox 2007; Williams and Jackson 2007; Hobbs et al. 2006; Hobbs et al. 2013). Novel ecosystems are defined as those experiencing alterations to historic abiotic regimes coupled with new species assemblages, resulting from a combination of varying degrees of environmental degradation or modification (e.g., land use changes) and multiple invasions (Hobbs et al. 2006; Hobbs et al. 2009). Novel systems provide an opportunity for insight into community assembly processes since a resorting or filtering of regional biotas is also a likely consequence of this decoupling from historic conditions.

An estimated $40 \%$ of the earth's land area may already be covered by novel ecosystems (Ellis et al. 2010; Foley et al. 2011; Barnosky et al. 2012), with many terrestrial examples (Cramer and Hobbs 2002; Mascaro et al. 2008; Lugo 2009; Lindenmayer et al. 2008; Hobbs et al. 2013). In marine systems, examples of novel ecosystems are increasingly being reported. For instance, algal blooms from non-point source runoff in the Gulf of Mexico have resulted in extensive dead zones and novel species interactions (Rabalais et al. 2002). Similarly, human-induced ocean acidification combined with rising ocean temperatures and pollution has left novel ecosystems in the wake of once thriving coral reefs (Fabricius 2005; Hoegh-Guldberg et al. 2007; Pandolfi 
et al. 2011). In contrast, examples of anthropogenic-driven impacts in freshwater systems using a novel ecosystem framework are lacking (but see Nilsson and Berggren 2000; Gido et al. 2009; King et al. 2011).

In freshwater systems, ecosystem degradation most often manifests itself as disruptions of natural hydrologic regimes coupled with alterations to connectivity (Rosenberg et al. 2000; Pringle 2001; Pringle 2003). Alterations to 'natural flow regimes' and aquatic species invasions are recognized as one of the most concerning global threats to aquatic biodiversity (Ricciardi and Rasmussen 1999; Dudgeon et al. 2006). Altered hydrology and connectivity from dams, impoundments, canals and levees, created for both water retention and diversion, can result in novel conditions for aquatic fauna that can limit or enhance dispersal abilities, alter resource fluctuations, and impose physiological constraints on native species that are evolutionarily adapted to particular historic regimes (Baxter 1977; Conley et al. 2000; Freeman et al. 2007; Franssen et al. 2013).

In the Everglades, an extensive network of canals and levees now bisects most of this rain-fed karstic wetland system. Built for water supply and flood control beginning in the $1880 \mathrm{~s}$, nearly $2500 \mathrm{~km}$ of canals and levees presently exist; impeding sheet flow and compartmentalizing the system (Light and Dineen 1994; Sklar et al. 2004). Canals in this region offer an opportunity to better understand how they function as novel habitat for both native and non-native fishes and how these novel conditions in turn influence distribution, abundance and assembly patterns in fish communities. Canals likely provide permanent deep-water refuges for biota, including fishes, which were historically rare or absent in the natural ecosystem (Gunderson and Loftus 1993), thus acting as novel 
aquatic habitats. However, canals also vary in characteristics which may result in a novelty gradient (Figure 1). In particular, variation in their connectivity to adjacent marshes, the influence of the natural seasonal hydrologic regime and habitat complexity can drive gradients in novelty that I hypothesize relate to the degree of invasion. Fish invasions have been prominent in this ecosystem (Fuller et al. 1999), particularly in canals, which can act as a source of invasions to protected areas such as Everglades National Park (ENP; Kline et al. 2013). Presently, 34 non-native fishes are considered established (i.e., they have reproductively viable populations; Shafland et al. 2008) in south Florida, of which 17 are established in ENP (Kline et al. 2013). These numbers are comparatively large relative to the low native fish diversity (35 species; Loftus 2000).

In this study, I examined native and non-native fish community structure in an Everglades canal network as a function of a gradient in novel conditions, particularly the loss of wetland connectivity and the natural influence of seasonal hydrology-conditions not reflective of the historic Everglades (McVoy et al. 2011). My specific objectives were to: (1) examine spatiotemporal variation in both the native and non-native fish communities in relation to the degree of novelty of canals, (2) quantify whether communities were randomly structured and (3) determine the relative importance of hydrological, habitat and spatiotemporal factors in driving community structure patterns. I expected that (1) increasing novelty will positively influence non-natives at the detriment of natives, (2) biotic interactions and abiotic conditions will influence natives and non-natives and thus nonrandom patterns will play a role in the assembly of fishes across space, and (3) the relative importance of structuring factors will differ between native and non-native assemblages. For instance, I expect hydrological variables to play a 
stronger role in structuring the native community, given that this community should be pre-adapted and thus responsive to hydrology, particularly the strong seasonal signature of hydrological variation (Trexler et al. 2005, Rehage and Trexler 2006).

\section{METHODS}

Everglades canals and novelty gradient

I sampled five canals (L-29, L-31N, L-31W, C-111 and L-67A) in the central and southern Everglades (Figure 2). To allocate sampling effort, I first classified the five canals into nine sampling units on the basis of connectivity to other canals or canal sections (i.e., presence of water control structures), and connectivity to adjacent Everglades marshes and habitat structure (i.e., presence of levees vs. a littoral zone directly connected to the marsh). To assess connectivity among canals and canal sections, I analyzed 20 years of flow data across water control structures. For example, the L-29 canal is leveed in the eastern portion but fully connected to the marsh in the western portion (Figure 2), and the two canal sections are separated by a water control structure (S-333) that moves water between the two sections but likely limits the exchange of biota since at times it is closed. Thus, I delineated these two canal sections as separate canal units (Table 1).

I then classified the nine canal sampling units based on their connectivity to marshes (hereafter CANALTYPE; Table 1): well-connected (WC), moderatelyconnected (MC), and leveed (L). This canal novelty gradient ranges from less novel canals that are well-connected to adjacent Everglades marshes, to more novel canals that 
have no direct connectivity (i.e., leveed canals). The WC canals $(n=3)$ are connected to longer hydroperiod marshes nearly year-round, experiencing a greater influence from the natural hydrologic regime (i.e., seasonal rainfall patterns) and have higher habitat complexity (Figure 1). The MC canals are, on average, only connected to adjacent shorter hydroperiod marshes during the wet season and have intermediate habitat complexity in their littoral zones. In contrast, $\mathrm{L}$ canals have no direct connectivity to marsh habitats, receive little influence from the natural hydrologic regime, and have low habitat complexity since they typically lack a littoral zone. These isolated, deep and low complexity habitats (i.e., minimal littoral zone) are unlike any natural aquatic habitat in the Everglades.

\section{Sampling design and effort}

I used a stratified random sampling scheme to allocate electrofishing effort across the $150 \mathrm{~km}$ of canal shoreline sampled. I sampled fish communities using a boatmounted, generator-powered electrofisher (two anode, one-cathode system with a SmithRoot GPP 9.0 control box). Electrofishing is an effective method for sampling fishes in freshwater habitats, including the Everglades, and electrofishing catch per unit effort (CPUE) provides a reliable index of fish abundance (Burkhardt and Gutreuter 1995;

Chick et al. 1999; Moulton et al. 2002, Chick et al. 2004; Rehage and Trexler 2006). For each sampling unit, I identified the maximum number of stations that could be sampled, each $200 \mathrm{~m}$ apart (Table 1). Since the average electrofishing sample covers $79.4 \pm 1.2 \mathrm{~m}$ of canal shoreline, $200 \mathrm{~m}$ spacing allows for a buffer zone between stations such that if adjacent stations were sampled, they may be considered independent samples. I 
conducted sampling three times a year in 2010-2011 and 2011-2012 in the wet, early dry, and the late dry seasons to examine how seasonal hydrological patterns influenced canal fish community structure. At each sampling event, 8 to 10 stations were randomly selected (10 in year 1: June 2010 to April 2011; and reduced to 8 in year 2: October 2011 to May 2012) for a total of 435 electrofishing samples.

Boat electrofishing is non-lethal and uses a flat-bottom aluminum boat to produce a standardized electrical field off the bow, so that fish may be electroshocked, immobilized and easily collected (Miranda and Boxrucker 2009). Each electrofishing sample (hereafter "bout") consisted of 300 seconds of standardized, intermittent power application at 3000 Watts (Burkhardt and Gutreuter 1995; Moulton et al. 2002). Since canal width (mean $=9.2 \mathrm{~m} \pm 0.09)$ is greater than the electric field, a shoreline side was targeted for sampling at each bout. If a canal had marsh connectivity (Table 1; Figure 2), then the marsh side of the canal was sampled (all WC and MC have marsh connectivity on only one side of the canal). If both sides were leveed, a shoreline was randomly selected for each bout. To ensure adequate sampling across the entire canal shoreline, bouts began from two meters out from the littoral zone edge in deep water (mean $=3.6 \mathrm{~m}$ $\pm 0.01)$ and crossed the littoral zone in a zigzag fashion at a 45 to 90 degree angle to the shore (Guy et al. 2009).

Upon capture by two netters positioned at the bow of the vessel, all fish were placed in a holding tank, identified, measured to the nearest 1-mm standard (SL) or total length (TL), and weighed. Native species were released after full recovery, while a subset of non-natives were euthanized using an overdose of anaesthetic (MS-222) and stored at $4^{\circ} \mathrm{C}$. I used electrofishing catch per unit effort (CPUE) as an index of fish abundance. 
Catch per unit effort consists of the sum of fishes caught and shocked in each bout, adjusted for the length of canal shoreline sampled (measured with a GPS unit; Pope et al. 2009; Boucek and Rehage 2013). Shocked fish included fish that were not caught by netters, but readily identified and counted while shocking. If fish identification was questionable, fish were not included in CPUE; nor were fish from the opposite shoreline. Thus, electrofishing CPUE consisted of the number of fish per $100 \mathrm{~m}$ of canal shoreline:

$$
\text { CPUE }=\left[\frac{\text { Fish netted }+ \text { fish shocked }}{\text { distance sampled }(\mathrm{m})}\right] * 100
$$

\section{Habitat complexity, abiotic and hydrologic conditions}

At the beginning of each bout, I measured habitat and abiotic conditions to examine their influence on community structure. I surveyed the littoral zone, recording water depth, plant species richness (hereafter PRICH) and percent cover (\%COVER) of submersed aquatic vegetation with a $0.5 \mathrm{~m}^{2}$ quadrat. Surveys were conducted every meter in a transect perpendicular from the shoreline out to $2 \mathrm{~m}$ into deep water. I then calculated mean littoral zone width (LZW) and depth (LZD). I also measured physicochemical conditions including dissolved oxygen (DO), ambient conductivity (COND) and temperature (TEMP) with a multisonder YSI unit, and water clarity (SECCHI) using a Secchi disk.

To quantify hydrologic connectivity, I recorded marsh connectivity at the time of each bout as a categorical variable (LOCALCONN; connected, not connected). In addition, I estimated regional connectivity by calculating the proportion of days each canal unit was connected (DAYSCONN) to the marsh for each sampling year using stage 
data provided by the Everglades Depth Estimation Network (EDEN, www. http://sofia.usgs.gov/eden/). Data from the closest gauges to each canal unit were used. I defined a canal unit as connected if the average marsh depth was $\geq 10 \mathrm{~cm}$, since at depths lower than $10 \mathrm{~cm}$, remaining standing water is scarce and not uniformly distributed across the marsh surface, making conditions unsuitable for fishes (Chick et al. 2004).

\section{Statistical analyses}

I used a three-step approach to examine variation and structure in canal fish communities. First, I fitted generalized linear models to examine spatiotemporal variation in abundance and richness of all fishes, and then of natives and non-natives separately. I then used multivariate tools to test for variation in community structure across space and time, for non-random patterns of species co-occurrence across space, and for the relative contribution of predictor variables.

I examined spatiotemporal variation in fish CPUE and richness of all fishes, natives only, and non-natives only, as well as habitat and abiotic variables, using twoway ANOVAs that tested the effects of CANALTYPE, SEASON and the interaction. To satisfy normality assumptions, CPUEs and all abiotic and habitat variables were $\log _{10}$ $(\mathrm{x}+1)$ transformed, except for \%COVER which was arcsine transformed. I used Tukey's HSD tests for pairwise comparisons, and conducted tests in SYSTAT ${ }^{\circledR}$ 13.0. Further, I calculated the overall proportion of natives and non-natives across all samples and compared these across CANALTYPE and SEASON using a chi-square in SigmaPlot $\mathbb{}$ 11.0. 
To examine variation in community structure, I constructed fourth-root transformed (to account for rare species) Bray-Curtis similarity matrices using the average relative abundance of all fish species for each canal by season combinations across sampling years (Clarke and Warwick 2001). I then conducted a two-way analysis of similarity (ANOSIM; 999 permutations) to test for the effects of CANALTYPE and SEASON. ANOSIM is a permutations test analogous to ANOVA and produces a Global $\mathrm{R}$ statistic between 0 and 1 where values above 0.4 typically indicate that groupings are distinct (Clarke and Warwick 2001). Non-metric multi-dimensional scaling (NMDS) plots were then constructed to illustrate dissimilarity among groupings using $\operatorname{Primer}^{\circledR}$ 6.0.

To more closely examine spatial variation in our data, I used null model analysis to test for non-random patterns of species co-occurrence (Gotelli 2000; Gotelli and Enstsminger 2010). I used Stone and Roberts' (1990) C-score index to measure the average number of unique 'checkerboard units' of species, using a presence/absence matrix of species across canal units. C-Scores significantly greater than expected by chance indicate less co-occurrence between species than in randomly assembled communities (Gotelli 2000). To measure the degree of non-randomness, I used standardized effect sizes (SES), which measure the difference in standard deviations between observed and simulated C-score values. Values $>2$ or $<-2$ with a tail probability of $P<0.05$ indicate a segregated or aggregated community respectively (Gotelli and McCabe 2002; Sanders et al. 2003). Prior to analyses, I removed rare species occurring in less than $1 \%$ of samples as their low abundance may be an artifact of sampling biases and can inflate estimates of co-occurrence patterns in simulation tests (Oliveira et al. 2005). I ran 5,000 randomizations of the original matrix separately for all fishes, natives only and 
non-natives only using the SIM9 algorithm (Gotelli 2000) in EcoSim 7.0 (Gotelli and Entsminger 2010).

To examine the relationship between fish community structure and predictor variables, I used distanced-based linear models (DISTLM; Legendre and Anderson 1999). The DISTLM procedure is a distanced-based redundancy analysis (dbRDA) that uses multivariate multiple regressions and performs a permutations test to model the variability of an assemblage matrix against multiple predictor variables (Anderson et al. 2008). I used DISTLM models to assess the relative contribution of five predictor variable sets: (1) spatial, (2) temporal, (3) hydrological, (4) habitat and (5) abiotic factors (Table 2). Spatial variables included each canal unit and CANALTYPE (WC, MC, L), temporal factors included the year of sampling (HYDROYR), hydrologic variables included the annual proportion of days each site was connected to the marsh (DAYSCONN) for the two years, the connectivity of the bout (LOCALCONN), and SEASON (Wet, early dry, late dry). Habitat variables included PRICH, LZD, LZW and \%COVER, and abiotic variables included DO, COND, TEMP, and SECCHI.

Models were fitted using a stepwise selection procedure. I used the Akaike Information Criterion for selecting the most parsimonious model corrected for small sample size (AICc), and $\mathrm{R}^{2}$ to evaluate the $\%$ of variation explained by each variable set (Anderson et al. 2008). I conducted DISTLM separately for the following assemblages: all fishes, natives only and non-natives only using Bray-Curtis resemblance matrices (Faith et al. 1987; Legendre and Gallagher 2001). Prior to analysis, all predictor variables were examined for co-linearity to eliminate redundant variables using principal components analysis and draftsman plots (Legendre and Anderson 1999; McArdle and 
Anderson 2001). The variable \%COVER was removed, and $\mathrm{I} \log _{10}(\mathrm{x}+1)$ transformed all continuous predictor variables. Lastly, I used DbRDA plots to visualize the results of DISTLM models with vectors of predictor variables overlaid. Statistical significance of predictor sets were assessed at $\alpha=0.05$ with 999 random permutations. DISTLMs were conducted using PERMANOVA+ for Primer ${ }^{\circledR} 6.0$ (Anderson et al. 2008). I then fitted simple regressions to better understand the relationship between native and non-native CPUE and key predictor variables identified in DISTLM and DbRDA analyses using SigmaPlot ${ }^{\circledR} 11.0$.

\section{RESULTS}

Spatiotemporal variation in habitat and abiotic conditions

I found marked spatiotemporal heterogeneity across seasons and canal type in the littoral habitat of sampled canals (Table 3; Figure 3). I detected gradients in littoral zone characteristics, such that habitat complexity, in terms of PRICH, \%COVER and LZW, increased with connectivity to surrounding marshes (WC $>\mathrm{MC}>\mathrm{L}$; Figure $3 \mathrm{~A}-\mathrm{C}$ ). WC canals had greater PRICH, \%COVER and LZW, MC canals were intermediate, and L canals had the lowest (Figure 3A-C). Habitats were least complex in L canals that had the smallest littoral zones, with fewer plant species providing less cover. Canal LZD were significantly greater in $\mathrm{WC}$ than $\mathrm{MC}$ and $\mathrm{L}$ canals $(\mathrm{WC}=81.9 \mathrm{~cm}, \mathrm{MC}=59.4 \mathrm{~cm}$, and $\mathrm{L}$ $=60.4 \mathrm{~cm}, P \leq 0.009$; Figure 3D). Across seasons, I detected significant variation in all habitat metrics, suggesting a general shrinking of the littoral zone between the wet and particularly the late dry season, noted by clear reductions in PRICH, \%COVER, LZW 
and LZD. But the magnitude of this effect was not the same across canal types. The greatest seasonal variation was noted in PRICH and \%COVER in canals with intermediate levels of marsh connectivity $(\mathrm{MC}>\mathrm{WC}>\mathrm{L}$; Figure 3).

Abiotic conditions showed less spatial variation, particularly for DO and TEMP, relative to habitat variables, but seasonality was marked (Table 3; Figure 4A-B). Across seasons, DO levels were consistently lowest in the wet season at $1.9 \mathrm{mg} \mathrm{L}^{-1}$ and highest in the late dry at $4.5 \mathrm{mg} \mathrm{L}^{-1}$ (Figure 4A), while TEMP was higher in the wet, intermediate in the late dry, and lowest in the early dry season (Figure 4B). The variable COND was higher in L canals $\left(0.63 \mu \mathrm{S} \mathrm{cm}^{-1}\right)$ relative to $0.57 \mu \mathrm{S} \mathrm{cm}^{-1}$ in $\mathrm{WC}$ and $0.56 \mu \mathrm{S} \mathrm{cm}^{-1}$ in $\mathrm{MC}$ canals $(P=0.0001)$, and was also consistently higher in the late dry $\left(0.64 \mu \mathrm{S} \mathrm{cm}^{-1}\right)$ compared to wet $\left(0.58 \mu \mathrm{S} \mathrm{cm}^{-1}\right)$ and early dry seasons $\left(0.53 \mu \mathrm{S} \mathrm{cm}^{-1}\right)$. This increase was most pronounced in WC and L canals, where COND increased by $13 \%$ and $16 \%$ respectively between early and late dry season samples (Figure 4C). MC canals were clearer than both WC and L canals (2.7 m vs. $2.5 \mathrm{~m})$. SECCHI showed little seasonal variation in MC and L canals, but in WC canals, it improved significantly between early and late dry season samples $(P=0.0001$; Figure 4D).

\section{Spatiotemporal variation in CPUE and richness}

Over the two years of sampling, I collected 19,151 fishes: 16,279 natives (39 spp) and 2,872 non-natives (15 spp; Appendix B). Across CANALTYPE, abundance of all fishes was highest in WC canals, intermediate in MC canals and lowest in L canals (Figure 5A; Table 4). This spatial variation was largely driven by native taxa which showed nearly a 14-fold increase in abundance as novelty decreased $(9.6$ fish/100 $\mathrm{m}$ in L 
canals vs. 37.9 fish/100m in MC canals vs. 136.6 fish/100 $\mathrm{m}$ in WC canals; Figure 5A). Non-native CPUE was almost an order of magnitude lower than native CPUE (8.7 vs. 64.9 fish/100 m), and showed a completely different pattern in relation to CANALTYPE. A nearly 8-fold increase in non-native fish abundance was observed between WC and MC/L canals (1.6 fish/100 $\mathrm{m}$ in WC canals vs. $11.7 \mathrm{fish} / 100 \mathrm{~m}$ in MC/L canals.

Patterns in species richness across CANALTYPE generally mirrored those of CPUE (Table 4). Across all taxa, richness was highest in WC canals, intermediate in MC canals and lowest in L canals (8.0, 7.1 and 4.6 spp respectively; Figure 5B). Native fish richness declined 3-fold as canals became less connected to marshes (7.4 spp in WC vs. $2.6 \mathrm{spp}$ in L canals). In contrast, non-native richness was highest in MC canals, intermediate in L canals, and extremely low in WC canals (2.6, 2.1 and 0.7 spp respectively).

Seasonality was marked in both the native and non-native CPUE, and its effect varied with CANALTYPE (Table 4). Native fishes showed a 6-fold increase between the wet and late dry season samples in WC (45.1 to 276.5 fish/100 m; Figure 6A), while increases were more modest (4-fold) and earlier in the dry season in MC canals (15.7 to $75.6 \mathrm{fish} / 100 \mathrm{~m})$. MC fish numbers then decreased to $34.3 \mathrm{fish} / 100 \mathrm{~m}$ in the late dry season. Among non-natives, I detected seasonality in MC and L canals, but none in WC canals where non-native numbers were very low ( $<1.8$ fish/100 m; Figure 6B). In L canals, non-native CPUE increased by almost $50 \%$ between wet and late dry season samples (10.2 to $14.8 \mathrm{fish} / 100 \mathrm{~m})$, while in MC canals non-natives increased by an average of 11.7 fish/100 m (from 6.9 to 18.6 fish/100m). But this increase was seen 
between the wet and early dry season matching the pattern in natives, and no difference was noted between early and late dry (18.6 vs. 14.9 fish/100 m, $P=0.614)$.

Similar to CPUE, the effect of seasonality on species richness varied across CANALTYPE (Table 4). In WC canals, native fish richness increased as seasons progressed, from an average of $5.9 \mathrm{spp}$ in the wet to $7.2 \mathrm{spp}$ in the early dry and $8.8 \mathrm{spp}$ in late dry season samples (Figure $6 \mathrm{C}, P<0.003$ ). The pattern was different in $\mathrm{MC}$ canals, with native richness peaking in the early dry season as did CPUE at 5.4 spp relative to $4.3 \mathrm{spp}$ in the late dry $(P=0.0001)$. L canals also showed an increase in native richness between wet/early dry and late dry samples ( 2.3 vs. $3.1 \mathrm{spp}, P=0.059)$. For nonnatives, seasonality in richness was only detected in MC canals, peaking in the early dry season at 3.2 spp relative to 2.0 and $2.5 \mathrm{spp}$ in wet and late dry seasons respectively (Figure 6D).

Relative contribution of non-native versus native taxa

Overall, non-natives accounted for $15.6 \%$ of all fish collected (Appendix B). Dominant non-natives included spotted tilapia, Asian swamp eels, African jewelfish, and Mayan cichlids, while native taxa were largely represented by sunfishes (particularly bluegill) followed by Florida gar, and largemouth bass. Although the overall contribution of non-natives appeared relatively small, spatially their contribution varied strongly and with increased novelty (Figure 7).The contribution of non-natives also varied strongly across CANALTYPE, accounting for $52.1 \%$ of fish caught in L canals, $27.3 \%$ in MC canals, and only $1.6 \%$ in WC canals $(P<0.0001)$. No variation in their contribution was 
detected seasonally within each canal type, although in L canals, a trend for an increase from $42.3 \%$ in the wet to $59.6 \%$ in the late dry season was observed $(P=0.087)$.

\section{Spatial and seasonal community structure}

Fish assemblages showed marked dissimilarity across canal types (Figure 8). WC and $\mathrm{L}$ communities were most distinct (Global $\mathrm{R}=0.897, P=0.001$ ), followed by WC and $\mathrm{MC}$ canals (Global $\mathrm{R}=0.746, P=0.001)$, and then $\mathrm{L}$ and $\mathrm{MC}$ canals $($ Global $\mathrm{R}=$ $0.482, \mathrm{P}=0.001)$. In contrast, dissimilarity as a function of season was very low (Global $=0.037, P=0.166)$. Results from the null model analysis indicated non-random patterns of species co-occurrence across the entire fish community (Obs. $C$ score $=2.4, P=$ 0.009 ), as well as when considering natives (Obs. $C$ score $=1.7, P=0.035)$ and nonnatives separately (Obs. $C$ score $=2.5, P=0.002$; Table 5 ). SES were positive and above 2.0 indicating that fishes tended to co-occur less frequently than expected by chance, indicating segregation among species.

\section{Relative contribution of predictor variable sets}

The best fitted DISTLM models explained about $40 \%$ of the variation in community structure (Table 6). Across all fishes, natives and non-natives, spatial factors consistently explained a much larger proportion of the variance relative to the other variable sets (34.5\%, 30.7\% and $29.1 \%$ respectively). Second in importance were hydrological variables across all taxa groups, while abiotic variables explained a minimal proportion of the variance, and habitat were only important predictors for all fishes and natives. Abiotic variables had greater explanatory power for non-natives than natives, 
whereas hydrological variables explained more variance for natives than non-natives. The dbRDA ordination was considered to be a good representation of fish community structure variation against predictor variables as both axes included $\sim 60 \%$ or greater of the fitted variation in all models. Overall, explanatory power was highest for natives, lowest for non-natives and intermediate for all fishes. Overall, the DAYSCONN explained the most variance for all three models. Regressions showed opposing relationships between native and non-native CPUE and DAYSCONN. Native fishes were more abundant as connectivity to surrounding marshes increased, while non-natives decreased with connectivity in a nonlinear fashion (Figure 10). Similar and opposing relationships were also detected as a function of habitat complexity (\% COVER and LZW). Natives were more abundant in more complex habitats, while the opposite was true for non-natives. Relationships were linear and consistently stronger for native fishes, while quadratic relationships provided the best fit for non-natives.

\section{DISCUSSION}

Human-caused modifications to both abiotic conditions and biotic composition are increasingly leading to novel ecosystems (Milton 2003; Hobbs 2006; Williams and Jackson 2007; Hobbs 2009; Hobbs 2013), and to gradients in such novelty that directly relate to the degree of alteration (King et al. 2011). I hypothesized a gradient in novelty in Everglades canals that related to the degree of fish invasion, such that not all man-made canals are created equal. I expected a lower invasion rate in canals with higher connectivity (i.e., year-around) to nearby marshes and thus lower novelty, and a higher invasion rate associated with canals with low connectivity to marshes (higher novelty). 
My findings matched this prediction well for native taxa, but the pattern was different for non-native fishes. Native fishe communities were more abundant and speciose as novelty decreased $(\mathrm{WC}>\mathrm{MC}>\mathrm{L}$ ). Non-native abundance was lowest in WC canals, but similar between MC and L canals, while non-native richness was lowest in WC canals, and contrary to predictions, was highest in $\mathrm{MC}$ and intermediate in L canals. Community structure was vastly different between canal types, and this structure was strongly influenced by spatial factors and secondarily by hydrological factors. Interestingly, I noted contrasting responses between native and non-native fishes and key hydrologic and habitat parameters.

The most notable finding was that spatial structuring appeared to be the most significant driver of assembly patterns in canal fishes. The location of a canal and the marsh it bisects as well as the degree of canal connectivity to the marsh habitat appeared to have a strong influence on fish assemblages. At small local scales, previous research showed that anthropogenic gradients result in a divergence in fish communities. For instance, Slawski et al. (2008) found that urbanization in the upper Des Plaines River watershed had a strong influence on fish species composition; shifting from cool-water riverine specialist to warm-water riverine generalist as urbanization in undammed tributaries increased. Here, we expected that given the relatively uniform nature of canals as aquatic habitats (i.e., extensive, deep with relatively low structure except for littoral zones), we would see a high degree of biotic homogenization across the canals sampled (e.g., McKinney and Lockwood 1999; Rahel 2002). For instance, Gido et al. (2009) found that in the novel habitat of reservoirs, patterns of fish community structure were homogenous across drainage basins and more so relative to natural stream assemblages. 
In contrast, the Everglades canal fish community was strongly spatially segregated, with distinct fish assemblages along canal types and particular canal units, despite that most canal units sampled in this study are continuously connected to each other via water control structures and some of the fishes sampled may exhibit high mobility (e.g., largemouth bass, Mayan cichlid; Moody 1960; Adams and Wolfe 2007).

Human alterations to aquatic systems can lower habitat quality by disrupting natural geomorphologic processes, spatial heterogeneity patterns and the natural fluctuation of resources (Ligon et al. 1995; Humborg et al. 1997; Poff et al. 1997; Rosenberg et al. 2000). For instance Bunn and Arthington (2002), summarized numerous studies that highlighted the negative effects on fishes as a result of altered flow and changes in habitat quality including the loss of fishes due to reduction in spawning habitat, loss of fishes adapted to turbid river habitats, and elimination of salmonids and pelagic spawning fishes. In Everglades canals, native fish richness and abundance declined sharply as hydrological and habitat complexity became more novel with extremely low numbers in the most novel, leveed canals. I suspect this pattern is indicative of poorer habitat quality for natives as canal littoral zones become smaller and less complex and as productivity and prey availability associated with the loss of connectivity to marshes is reduced. Although canals may provide deep, suitable habitat for larger taxa, the connectivity to marshes and littoral zones likely enhances fish numbers, particularly of smaller and juvenile taxa. For instance, more complex littoral zones within reservoirs can support a higher diversity in fish communities and has a greater potential in maintaining native populations, especially juveniles that use these areas to avoid predation (Fernando and Holčík 1991; Mathews et al. 2004). Differences 
in native fish abundance between $\mathrm{WC}$ and $\mathrm{MC}$ canals likely reflect the variation in productivity of the marshes they bisect. WC canals connect to longer hydroperiod marshes almost year-round, which have been shown to have higher fish abundances relative to the shorter hydroperiod marshes that connect to $\mathrm{MC}$ canals only during the wet season (Chick et al. 2004; Green et al. 2006). Additionally, canal connectivity to marsh species pools with different community structure may also have contributed to the observed patterns in this Study. For instance, Parkos et al. (2011) documented differences in fish community structure in WCA 3A marshes which connect to well-connected canals compared to fishes within ENP marshes which connected to moderately-connected canals.

Variation in the degree of marsh connectivity across canals also influences the role of canals as drydown refuges. In pulsing systems, seasonal variation in rainfall drives patterns of inundation and thus habitat availability for fishes and other aquatic taxa, such that fish survival is highly dependent on refuge size, the intensity of the drydown period and mobility (Magoulick and Kobza 2003). The recurrent pattern of seasonal drying in Everglades marshes is a major driver of fish community dynamics as fish move to both natural (i.e., alligator holes, solution holes and estuarine mangrove creeks (Loftus and Kushlan 1987; Kobza et al. 2004; Rehage and Loftus 2007; Parkos et al. 2011; Rehage and Boucek 2013), and artificial (i.e., canals, Rehage and Trexler 2006) deep refuges as water levels recede. We saw further evidence of the use of canals as drydown habitat in this study, but the timing varied among canal types, matching the hydroperiod of surrounding marshes. In MC canals, abundance of natives peaked sooner reflecting earlier drying of the surrounding shorter-hydroperiod marshes followed by reductions by 
$\sim 50 \%$ in the late dry season, which is likely attributed to mortality via predation. Similar decreases in fish abundance later in the dry season have been documented in mangrove creeks, which serve as important drydown habitats in the southern Everglades (Rehage and Boucek 2013), and have been attributed to predation of the smaller taxa by larger fishes (Boucek and Rehage 2013). Interestingly, non-native taxa showed a similar increase in MC canals, indicating that they are also likely entering canals from marshes as native fishes do, but their numbers did not experience a decrease later in the season. In WC canals, seasonal increases occurred but later in the dry season. Although canals may be lower quality habitats because of the high abundance of predators and low complexity, they could provide better habitat in extreme droughts, playing a greater role in the recolonization of marshes during these events. Further research into their role in normal vs. extreme drying events is needed.

For non-natives, the most notable pattern was their increase in relative contribution as novelty increased, peaking at $>50 \%$ of total fish in L canals. This further strengthens the argument that more novel canal habitats offer less suitable habitat for native fish species and likely facilitates the establishment of opportunistic invaders that can withstand less than favorable conditions. In lotic systems, novel conditions have often been linked to shifts in assemblages from natives to phenotypically plastic and more tolerant non-natives (Weaver and Garman 1994; Onorato et al. 1998; Walters et al. 2003). The extremely low contribution of non-natives in WC may relate to variation in the role of canals as thermal refugia. Just prior to the beginning of this study in 2010, a severe cold event lead to a large mortality event for temperature sensitive taxa (Adams et al. 2012; Matich and Heithaus 2012; Boucek and Rehage 2013), including non-natives. 
We suspect non-natives contributed to a larger although still small part of the fish community in WC canals prior to the 2010 cold snap. Unpublished records from the Florida Fish and Wildlife Conservation Commission (FWC) point to non-natives accounting for about $8.1 \%$ of fishes caught in the L67A canal (2006-2009), a WC canal I sampled. Temperature records from the cold snap indicated that in WC canal units, the pattern of water flow (from marshes into canals) reached low temperatures in the range of lethal limits of many non-natives (e.g., Schofield et al. 2009; Schofield and Huge 2010) while canals elsewhere remained warmer (J Kline, pers. Comm.).

Previous work points to the relation and feedback between hydrological disturbance and invasions (Marchetti et al. 2004; Leprieu 2008). Not unlike these studies, I documented opposing relationships between marsh connectivity and the abundance of native versus non-native taxa. These relationships suggest, at minimum, that natives and non-natives are responding to the natural hydrology of the system in different ways. Kiernan et al. (2012) showed that restoration of the natural hydrological regime, can lead to the recovery of natives in heavily invaded California streams. Whether Everglades restoration could have the same detrimental effects on non-natives, to the benefit of native taxa is not known and merits further work. Regardless, canals are permanent features of the Everglades landscape, since most of this conveyance network that provides water supply, flood control and reroutes water delivery into natural areas will remain in place. Overall, this study represents the first comprehensive assessment of fishes in Everglades canals, providing insight into the factors influencing native and nonnative abundance and assembly patterns and contributing to our understanding of this novel but permanent habitat of the system. 
TABLE 1. Classification of the 9 canal sampling units by CANALTYPE and the estimated proportion of days connected to adjacent marshes for each of the 2 hydrologic years of this study. Marsh water level data were obtained from EDEN. Also shown are the number of sampleable stations per canal unit (see Figure 1 for canal locations).

\begin{tabular}{|c|c|c|c|c|c|c|}
\hline \multirow[b]{2}{*}{ Canal Unit } & \multirow{2}{*}{$\begin{array}{c}\text { Number of } \\
\text { Sample } \\
\text { Stations }\end{array}$} & \multicolumn{3}{|c|}{ CANALTYPE } & \multicolumn{2}{|c|}{$\begin{array}{c}\text { Proportion of Days } \\
\text { Connected }(\%)\end{array}$} \\
\hline & & $\begin{array}{l}\text { Well- } \\
\text { Connected } \\
\text { (WC) }\end{array}$ & $\begin{array}{l}\text { Moderately- } \\
\text { Connected } \\
\text { (MC) }\end{array}$ & $\begin{array}{l}\text { Leveed } \\
\text { (L) }\end{array}$ & Year 1 & Year 2 \\
\hline L-67A & 204 & $\mathrm{X}$ & & & 100 & 88.8 \\
\hline L-29 West & 89 & $X$ & & & 96.2 & 81.1 \\
\hline L-29 East & 97 & $\mathrm{X}$ & & & 90.5 & 87.8 \\
\hline L-31W North & 51 & & $\mathrm{X}$ & & 42.2 & 27.5 \\
\hline L-31W South & 33 & & $\mathrm{X}$ & & 75.9 & 64.2 \\
\hline C-111 South & 53 & & $\mathrm{X}$ & & 64.3 & 51 \\
\hline L-31N North & 57 & & & $X$ & 0 & 0 \\
\hline L-31N South & 84 & & & $X$ & 0 & 0 \\
\hline C-111 North & 93 & & & $X$ & 0 & 0 \\
\hline
\end{tabular}


TABLE 2. Summary of the five predictor variables sets used in variance partitioning analyses (DISTLM) to examine their relative contribution to native and non-native fish community structure. These include: 1) spatial ( $\mathrm{n}=2$ variables), 2) temporal $(\mathrm{n}=1), 3)$ hydrological $(n=3), 4)$ habitat $(n=3)$ and 5$)$ abiotic $(n=4)$ factors.

\begin{tabular}{|c|c|c|}
\hline Predictor Set & Predictors & Description \\
\hline \multirow[t]{2}{*}{ 1. Spatial } & CANALUNIT & $\begin{array}{l}\text { Categorical: } 1 \text { of } 9 \text { sampling sites (L-67A, L-29W, L-29E, L-31N North, } \\
\text { L-31N South, L-31W North, L-31W South, C-111 North, C-111 South) }\end{array}$ \\
\hline & CANALTYPE & $\begin{array}{l}\text { Categorical: Sampling units grouped by their connection to Everglades } \\
\text { marshes (WC: Well Connected, MC: Moderately Connected, L: Leveed) }\end{array}$ \\
\hline 2. Temporal & HYDROYR & Hydrological year of study (Year 1: 2010-2011, Year 2: 2011-2012) \\
\hline \multirow[t]{3}{*}{ 3. Hydrological } & SEASON & Categorical: Wet, early dry (ED) and late dry (LD) \\
\hline & LOCALCONN & $\begin{array}{l}\text { Categorical: Local scale connectivity to Everglades marshes at the time of } \\
\text { sample (Yes or No) }\end{array}$ \\
\hline & DAYSCONN & $\begin{array}{l}\text { Regional scale connectivity-Estimated proportion of days each site was } \\
\text { connected to adjacent Everglades marshes for years } 1 \text { and } 2 \text { of this study }\end{array}$ \\
\hline \multirow[t]{3}{*}{ 4. Habitat } & PRICH & Plant species richness recorded during littoral zone surveys. \\
\hline & LZW & Mean width $(\mathrm{m})$ of the littoral zone \\
\hline & LZD & Mean water depth $(\mathrm{cm})$ of the littoral zone \\
\hline \multirow[t]{4}{*}{ 5. Abiotic } & SECCHI & Water Clarity (m) measured using a secchi disk \\
\hline & COND & Ambient conductivity (us/cm) using a YSI meter \\
\hline & TEMP & Water temperature $\left({ }^{\circ} \mathrm{C}\right)$ measured using a YSI meter \\
\hline & DO & Dissolved oxygen $(\mathrm{mg} / \mathrm{L})$ measured using a YSI meter \\
\hline
\end{tabular}


TABLE 3. Summary of ANOVAs testing variation among CANALTYPE (WC, MC, L), SEASON (wet, early dry, late dry), and the interaction for abiotic and habitat (littoral zone) variables.

\begin{tabular}{|c|c|c|c|c|c|c|c|c|c|}
\hline \multirow{2}{*}{ Response Variable } & \multicolumn{3}{|c|}{ CANALTYPE } & \multicolumn{3}{|c|}{ SEASON } & \multicolumn{3}{|c|}{ CANALTYPE x SEASON } \\
\hline & $d f$ & $F$ & $P$ value & $d f$ & $F$ & $P$ value & $d f$ & $F$ & $P$ value \\
\hline \multicolumn{10}{|l|}{ Habitat variables } \\
\hline$\%$ COVER & 2,426 & 53.2 & $<0.0001$ & 2,426 & 22.9 & $<0.0001$ & 4,426 & 6.3 & $<0.0001$ \\
\hline PRICH & 2,426 & 75.1 & $<0.0001$ & 2,426 & 33.8 & $<0.0001$ & 4,426 & 3.1 & 0.0169 \\
\hline LZW & 2,426 & 129.5 & $<0.0001$ & 2,426 & 28.2 & $<0.0001$ & 4,426 & 2.4 & 0.0489 \\
\hline LZD & 2,426 & 7.4 & $<0.0001$ & 2,426 & 30.5 & $<0.0001$ & 4,426 & 0.9 & 0.4475 \\
\hline \multicolumn{10}{|l|}{ Abiotic variables } \\
\hline SECCHI & 2,426 & 6.8 & 0.0013 & 2,426 & 11.1 & $<0.0001$ & 4,426 & 7.3 & $<0.0001$ \\
\hline TEMP & 2,426 & 0.5 & 0.6404 & 2,426 & 101.1 & $<0.0001$ & 4,426 & 2.5 & 0.4500 \\
\hline DO & 2,426 & 1.5 & 0.2365 & 2,426 & 93.9 & $<0.0001$ & 4,426 & 1.9 & 0.1163 \\
\hline COND & 2,426 & 16.8 & $<0.0001$ & 2,426 & 26.9 & $<0.0001$ & 4,426 & 3.1 & 0.0156 \\
\hline DAYSCONN & 2,426 & $2,415.0$ & $<0.0001$ & 2,426 & 0.9 & 0.4090 & 4,426 & 0.2 & 0.9530 \\
\hline
\end{tabular}


TABLE 4. Summary of ANOVAs testing variation among CANALTYPE (WC, MC, L), SEASON (wet, early dry, late dry), and the interaction for total CPUE and species richness separately for all taxa, natives only and non-natives only.

\begin{tabular}{|c|c|c|c|c|c|c|c|c|c|}
\hline \multirow{2}{*}{ Variables } & \multicolumn{3}{|c|}{ CANALTYPE } & \multicolumn{3}{|c|}{ SEASON } & \multicolumn{3}{|c|}{ CANALTYPE x SEASON } \\
\hline & $d f$ & $F$ & $P$ value & $d f$ & $F$ & $P$ value & $d f$ & $F$ & $P$ value \\
\hline \multicolumn{10}{|l|}{ Abundance } \\
\hline All fishes & 2,404 & 92.7 & $<0.0001$ & 2,404 & 35 & $<0.0001$ & 4,404 & 26.2 & $<0.0001$ \\
\hline Natives only & 2,400 & 140.5 & $<0.0001$ & 2,400 & 31.7 & $<0.0001$ & 4,400 & 25.1 & $<0.0001$ \\
\hline Non-natives only & 2,416 & 76.7 & $<0.0001$ & 2,416 & 2 & 0.1336 & 4,416 & 5.9 & 0.0001 \\
\hline \multicolumn{10}{|l|}{ Richness } \\
\hline All fishes & 2,426 & 71.9 & $<0.0001$ & 2,426 & 16.2 & $<0.0001$ & 4,426 & 10.3 & $<0.0001$ \\
\hline Natives only & 2,426 & 240.2 & $<0.0001$ & 2,426 & 22.6 & $<0.0001$ & 4,426 & 11.1 & $<0.0001$ \\
\hline Non-natives only & 2,425 & 93.3 & $<0.0001$ & 2,425 & 1.7 & 0.9142 & 4,425 & 5.1 & 0.0006 \\
\hline
\end{tabular}


TABLE 5. Null-model analysis results for all fishes, natives and non-natives testing for non-random patterns of species co-occurrence across space.

\begin{tabular}{lcccc}
\hline Assemblage & $\begin{array}{c}\text { Observed } \\
C \text { score }\end{array}$ & $\begin{array}{c}\text { Simulated } \\
C \text { score }\end{array}$ & Effect Size & $P$ value \\
\hline \hline All fishes & 2.4 & 2.3 & 2.9 & 0.009 \\
Natives only & 1.7 & 1.6 & 2.1 & 0.035 \\
Non-natives only & 2.5 & 2.3 & 3.7 & 0.002 \\
\hline
\end{tabular}


TABLE 6. Summary of DISTLM analyses for the best model (based on AICc) showing the relative contribution of predictor variable sets (space, time, hydrological, habitat and abiotic variables) based on Bray-Curtis resemblance matrices for all fishes, natives only and non-natives only.

\begin{tabular}{|c|c|c|c|c|c|c|}
\hline \multirow{2}{*}{ Variable Set } & \multicolumn{2}{|c|}{ All Fishes } & \multicolumn{2}{|c|}{ Natives Only } & \multicolumn{2}{|c|}{ Non-natives Only } \\
\hline & $\%$ & $P$ value & $\%$ & $P$ value & $\%$ & $P$ value \\
\hline Space & 34.5 & 0.001 & 30.7 & 0.001 & 29.1 & 0.001 \\
\hline Time & 0.7 & 0.001 & 1.1 & 0.001 & 0.9 & 0.001 \\
\hline Hydrological & 6.1 & 0.001 & 7.6 & 0.001 & 4.5 & 0.001 \\
\hline Habitat & 1.5 & 0.001 & 1.3 & 0.001 & - & - \\
\hline Abiotic & 1.5 & 0.001 & 1.4 & 0.001 & 3.2 & 0.001 \\
\hline$R^{2}:$ & 44.4 & & 42.1 & & 37.6 & \\
\hline
\end{tabular}


FIGURE 1. Conceptual diagram depicting hypothesized relationships between native (black line) and non-native (dotted grey line) fish species richness and abundance and increasing novelty in Everglades canals. Canals with higher novelty are characterized by lower connectivity to natural habitats, lower influence of the natural hydrological regime, and lower habitat complexity.

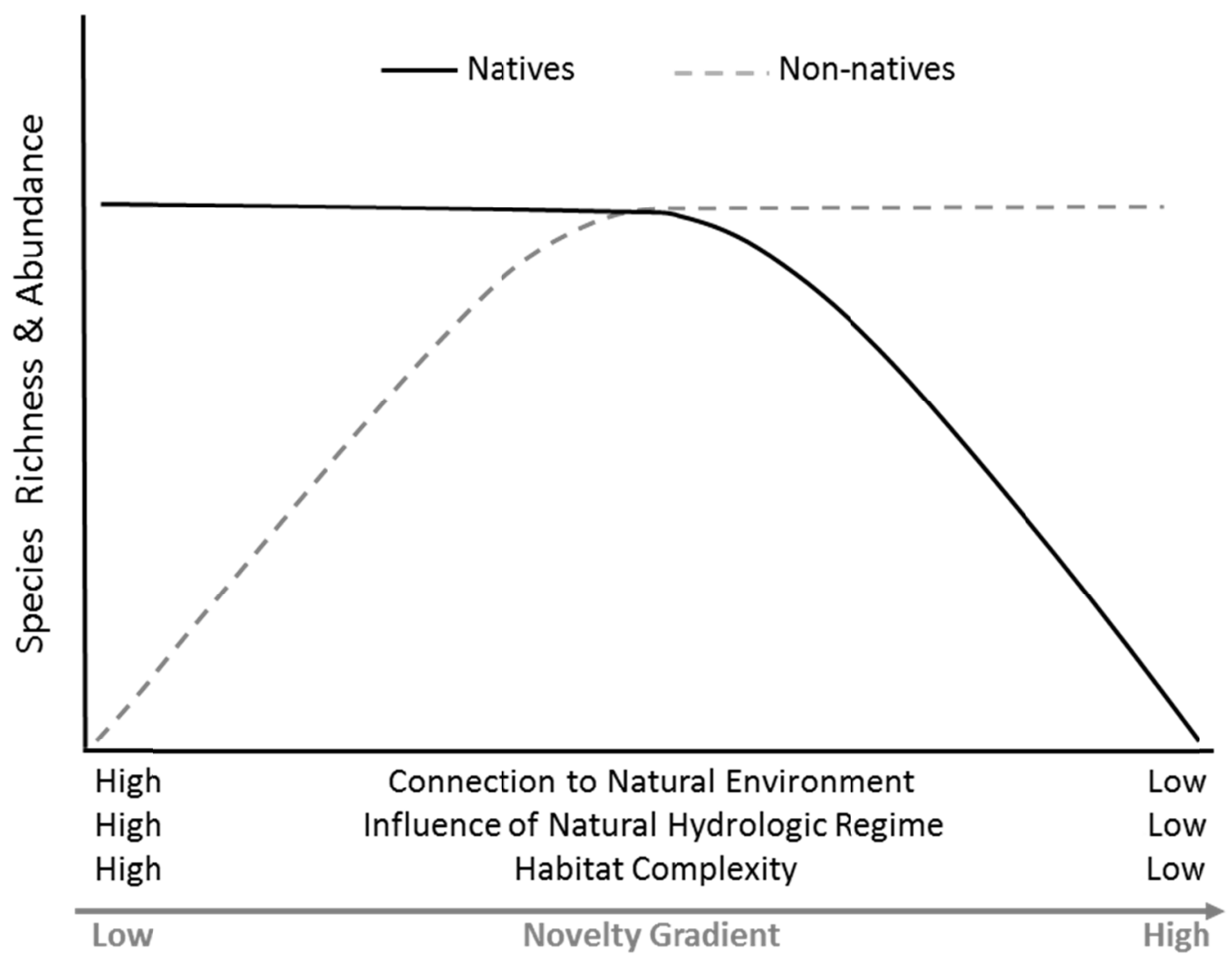


FIGURE 2. Map showing the 9 canal sampling units spanning across the southern and central portions of the Everglades. Sites are coded based on their connectivity to marshes: $\mathrm{WC}=$ well-connected, $\mathrm{MC}=$ moderately-connected, and $\mathrm{L}=$ leveed canals, and thus degree of increasing novelty. WC canals are connected to marshes year-around, MC canals are connected only at high water conditions, and L canals are completely disconnected from surrounding marsh habitats.

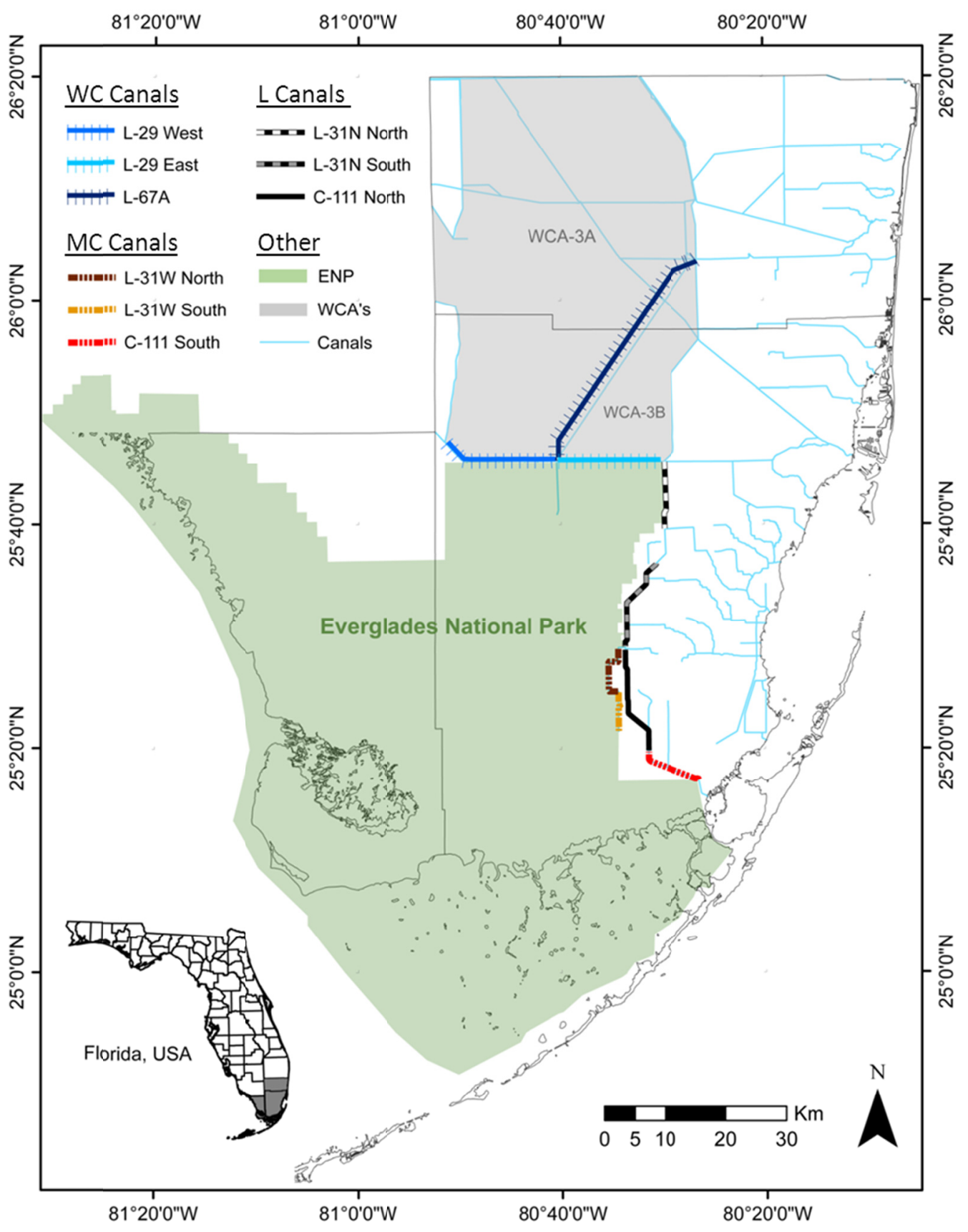


FIGURE 3. Habitat characteristics along the canal littoral zone: (A) PRICH, (B) \%COVER, (C) LZW, and (D) LZD shown by CANALTYPE (WC, MC, L) and SEASON. Shown are means \pm SEM.

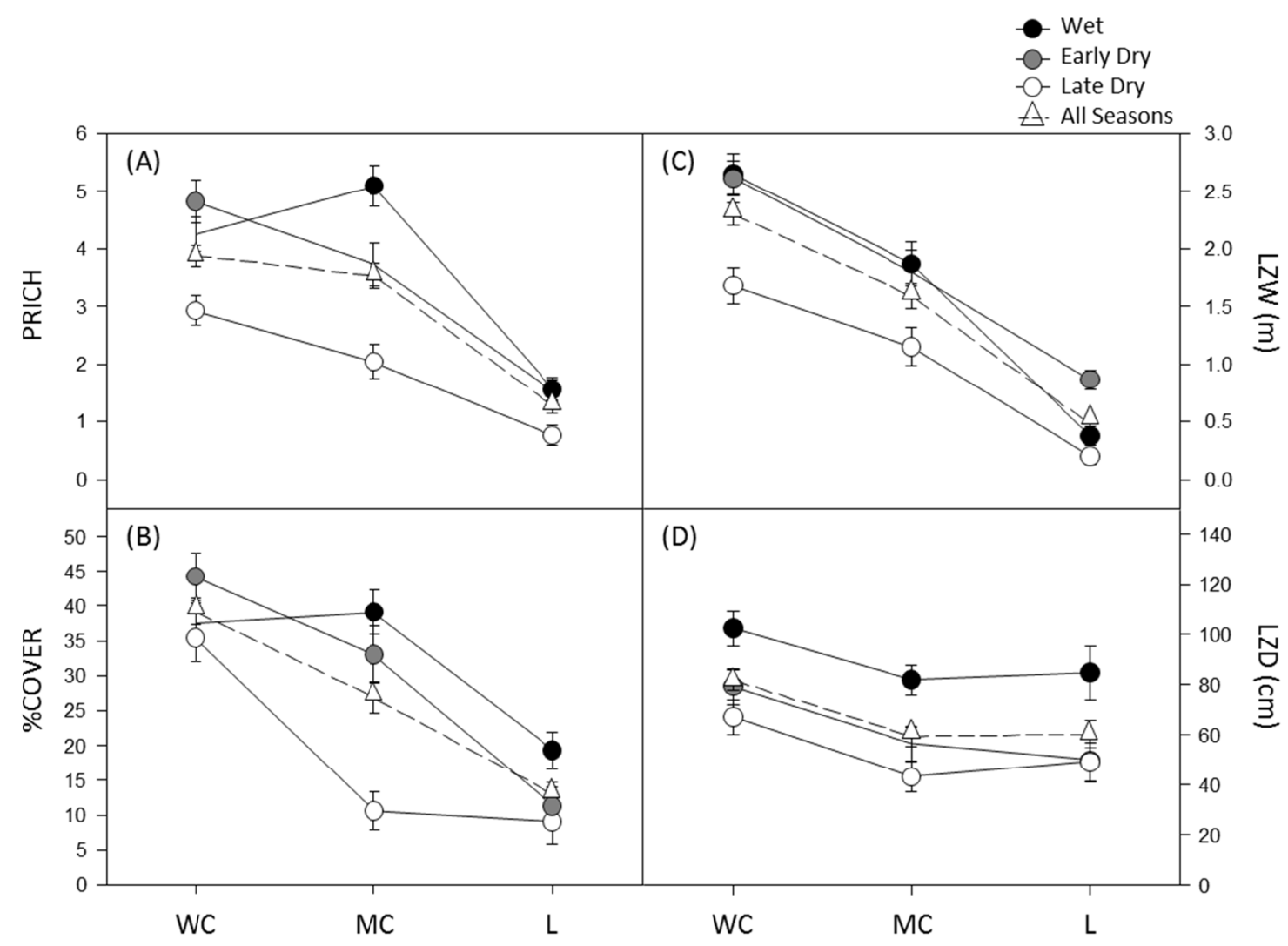


FIGURE 4. Abiotic variables: (A) DO, (B) TEMP, (C) COND, and (D) SECCHI shown by CANALTYPE (WC, MC, L) and SEASON. Shown are means \pm SEM.

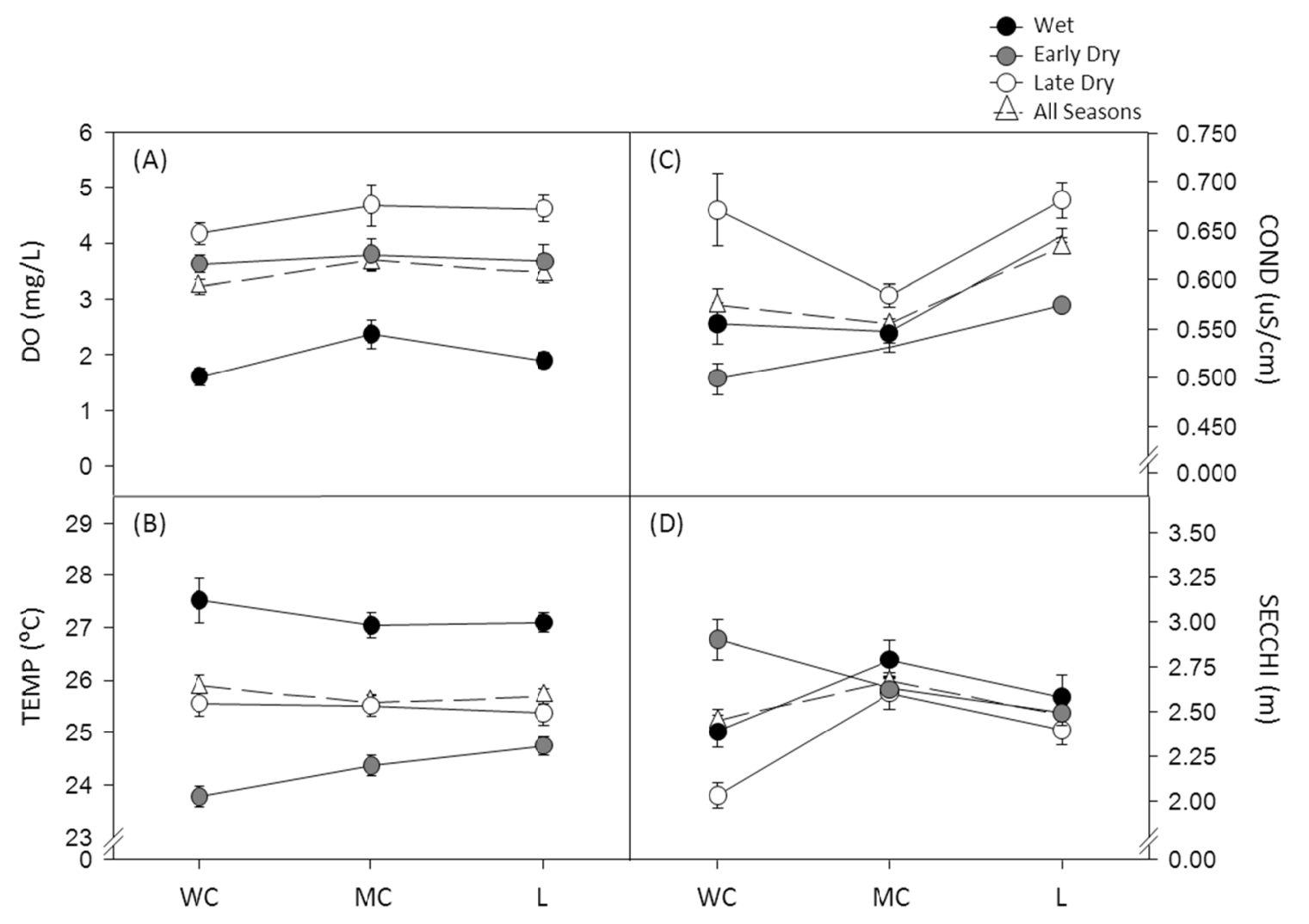


FIGURE 5. (A) CPUE (\# fish/100m) and (B) species richness for all fishes, natives and non-natives across CANALTYPE. Shown are means $\pm \mathrm{SEM}$.

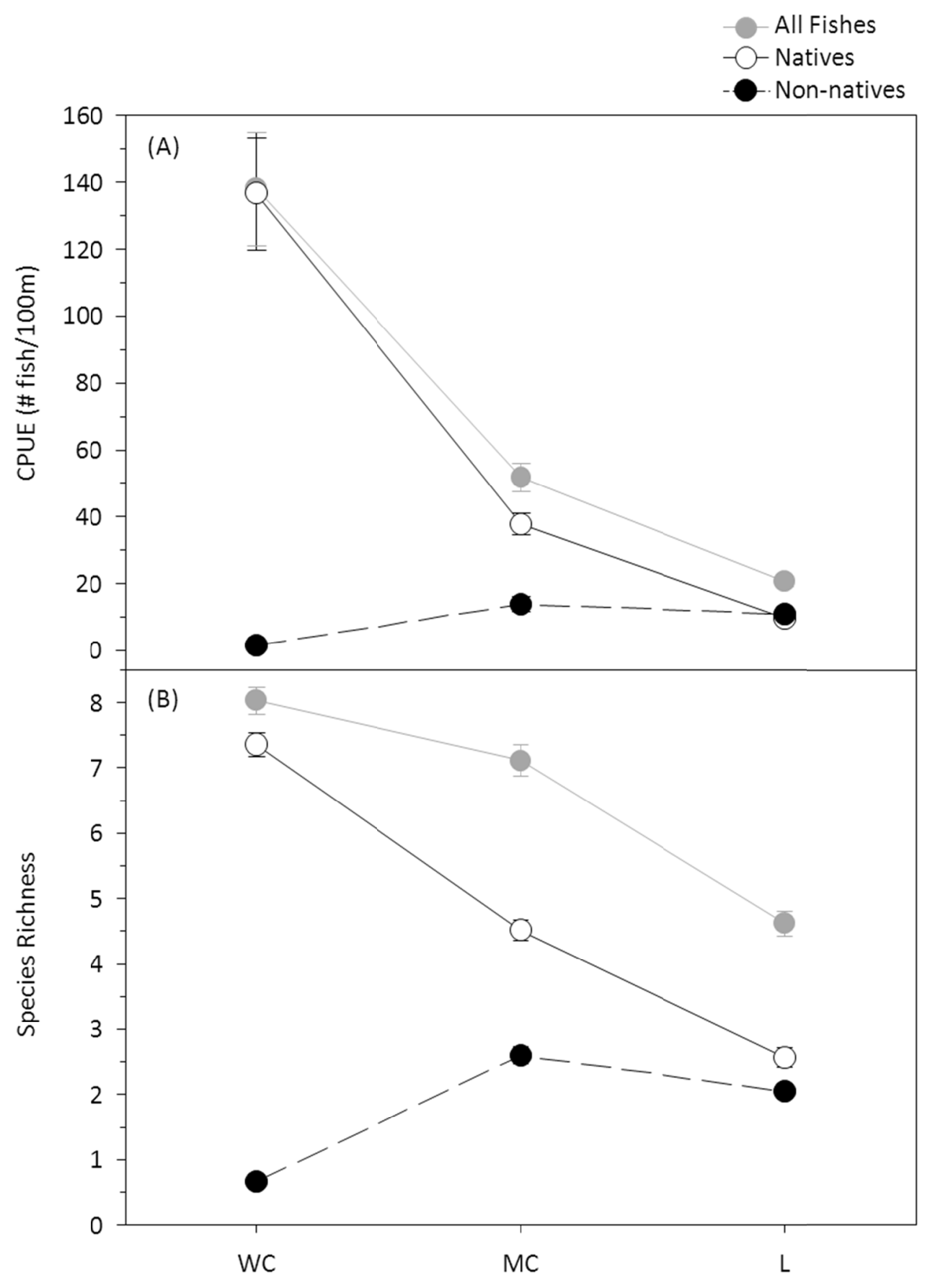


FIGURE 6. Fish CPUE (\# fish/100m) for (A) natives and (B) non-natives, and species richness for (C) natives and (D) non-natives across CANALTYPE (WC, MC, and L) and SEASON. Shown are means \pm SEM.

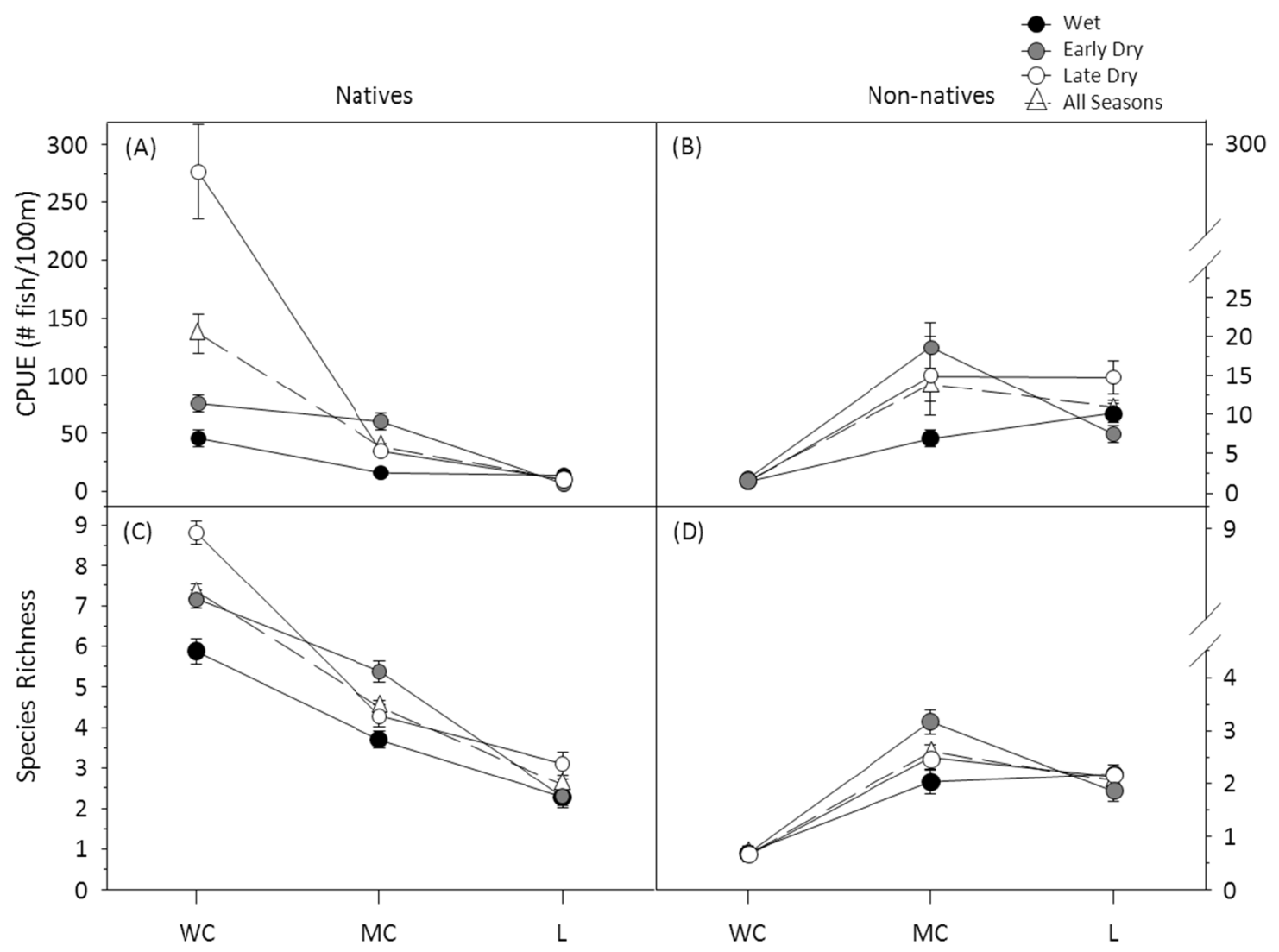


FIGURE 7. Relative compositon of native vs. non-native taxa across CANALTYPE (WC, MC, and L canal units) for (A) wet, (B) early dry, and (C) late dry season samples.
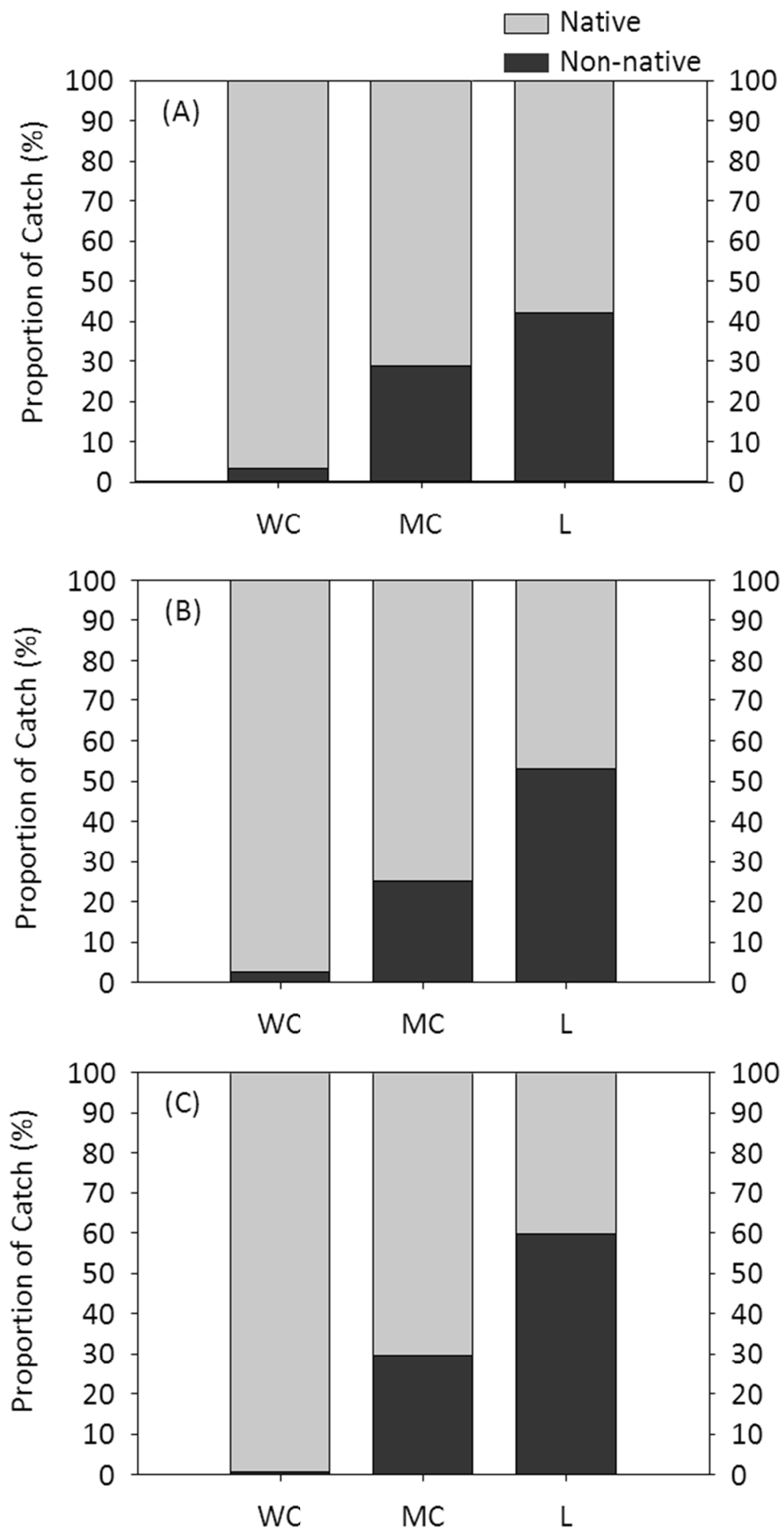
FIGURE 8. NMDS ordination illustrating variation in community structure for all taxa. Symbols represent the average community structure of each canal unit across SEASON and HYDROYR sampled and as a function of CANALTYPE (WC, MC, L)

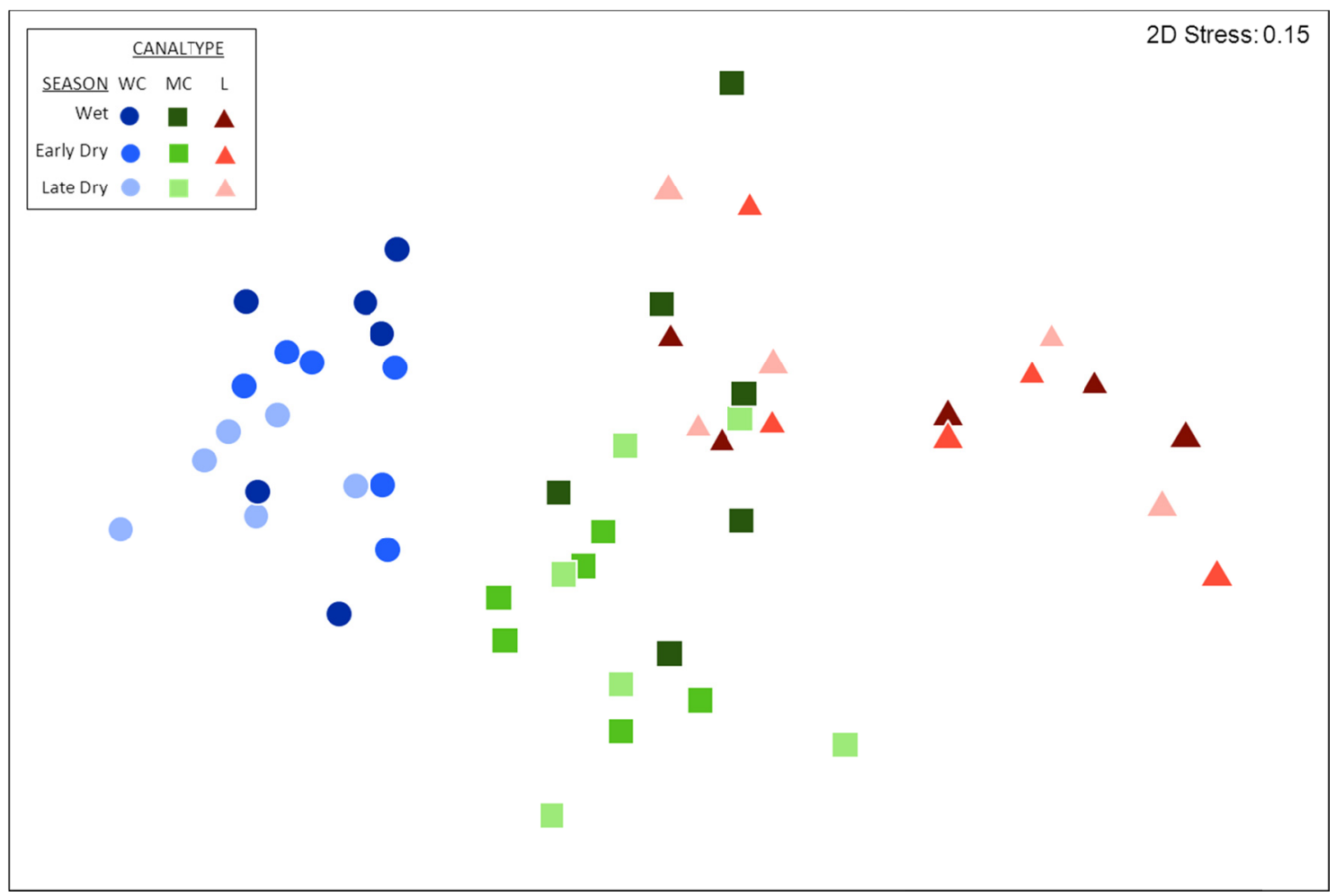


FIGURE 9. dbRDA of the stepwise selected predictor variables for (A) all fishes, (B) natives and (C) non-natives. Individual predictor variables (see Table 2$)$ from the best model are shown $(\mathrm{p}<0.01$ significance) Vectors represent the direction and strength of each predictor variables relationship against the dbRDA axis.

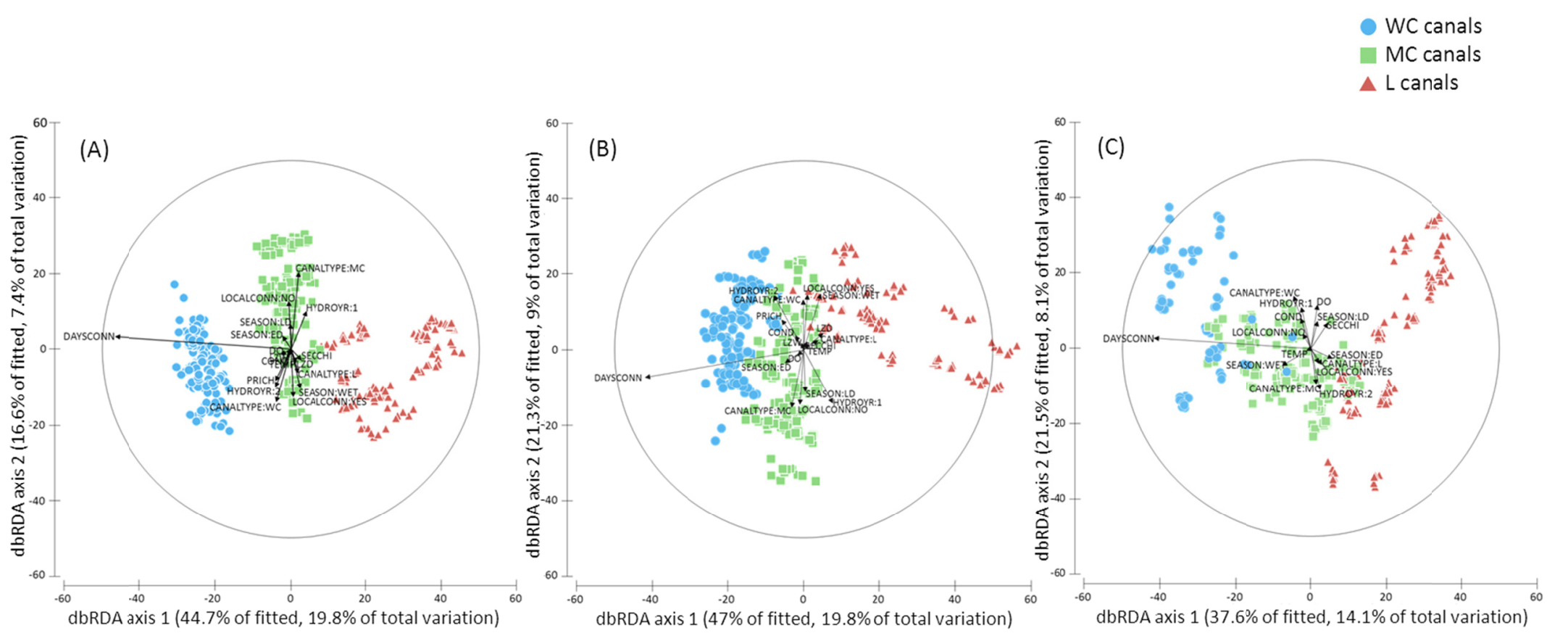


FIGURE 10. Best fit regression models (linear and quadratic) fitted to native and non-native CPUE (\# of fish/100m) and hydrologic and habitat complexity variables: DAYSCONN, \%COVER, and LZW.

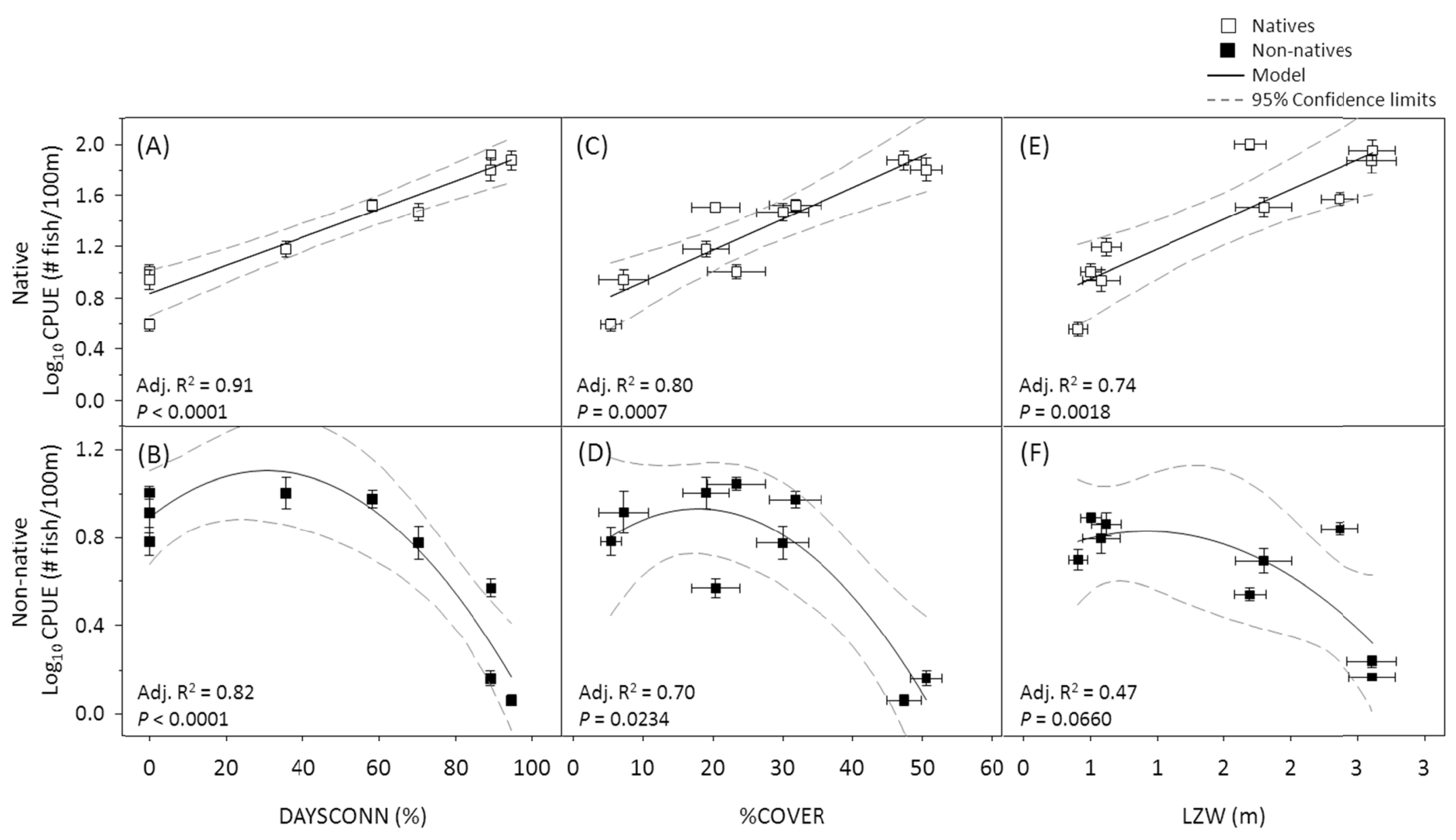




\section{LITERATURE CITED}

Adams AJ, and Wolfe RK (2007) Occurrence and persistence of non-native Cichlasoma urophthalmus (family Cichlidae) in estuarine habitats of south-west Florida (USA): environmental controls and movement patterns. Marine and Freshwater Research 58: 921-930

Adams AJ, Hill JE, Kurth BN and Barbour AB (2012) Effects of a severe cold event on the subtropical, estuarine dependent common snook, Centropomus undecimalis. Gulf and Caribbean Research 24:13-21

Anderson MJ, Gorley RN and Clarke KR (2008) PERMANOVA+ for PRIMER: Guide to Software and Statistical Methods. PRIMER-E, Plymouth, UK

Barnosky AD, Hadly EA, Bascompte J, Berlow EL, Brown JH, Fortelius M, Getz WM, Harte J, Hastings A, Marquet PA, Martinez ND, Mooers A, Roopnarine P, Vermeij G, Williams JW, Gillespie R, Kitzes J, Marshall C, Matzke N, Mindell DP, Revilla E, and Smith AB (2012) Approaching a state shift in Earth's biosphere. Nature 486:5258

Baxter RM (1977) Environmental effects of dams and impoundments. Annual Review of Ecology and Systematics 8:255-283

Boucek RE, and Rehage JS (2013) No free lunch: displaced marsh consumers regulate a prey subsidy to an estuarine consumer. Oikos, accepted.

Bunn SE, and Arthington AH (2002) Basic principles and ecological consequences of altered flow regimes for aquatic biodiversity. Environmental management 30:492507

Burkhardt RW, and Gutreuter S (1995) Improving electrofishing catch consistency by standardizing power. North American Journal of Fisheries Management 15:375-381

Chick JH, Coyne S, and Trexler JC (1999) Effectiveness of airboat electrofishing for sampling fishes in shallow, vegetated habitats. North American Journal of Fisheries Management 19:957-967

Chick JH, Ruetz CR III, and Trexler JC (2004) Spatial scale and abundance patterns of large fish communities in freshwater marshes of the Florida Everglades. Wetlands, 24: $652-664$

Clarke KR and Warwick RM (2001) Changes in marine communities: an approach to statistical analyses and interpretation, 2nd edition. National Environmental Research Council, Plymouth Marine Laboratory, Plymouth, UK 
Conley DJ, Stalnacke P, Pitkanen H, and Wilander A (2000) The transport and retention of dissolved silicate by rivers in Sweden and Finland. Limnology and Oceanography $45: 1850-1853$

Cramer VA, and Hobbs RJ (2002) Ecological consequences of altered hydrological regimes in fragmented ecosystems in southern Australia: impacts and possible management responses. Austral Ecology, 27: 546-564

Didham RK, Tylianakis JM, Gemmell NJ, Rand TA, and Ewers RM (2007) Interactive effects of habitat modification and species invasion on native species decline. Trends in Ecology and Evolution 22:489-496

Dudgeon D, Arthington AH, Gessner MO, Kawabata ZI, Knowler DJ, Lévêque C, Naiman RJ, Prieur-Richard A-H, Soto D, Stiassny MLJ, and Sullivan CA (2006) Freshwater biodiversity: importance, threats, status and conservation challenges. Biological Reviews 81:163-182

Ellis EC, Klein Goldewijk K, Siebert S, Lightman D, and Ramankutty N (2010) Anthropogenic transformation of the biomes, 1700 to 2000. Global Ecology and Biogeography 19:589-606

Fabricius KE (2005) Effects of terrestrial runoff on the ecology of corals and coral reefs: review and synthesis. Marine pollution bulletin 50:125-146

Faith DP, Minchin PR and Belbin L (1987) Compositional dissimilarity as a robust measure of ecological distance. Vegetatio 69:57-68

Fernando CH, and Holčík J (1991) Fish in reservoirs. Internationale Revue der gesamten Hydrobiologie und Hydrographie 76:149-167

FoleyJA, Ramankutty N, Brauman KA, Cassidy ES, Gerber JS, Johnston M, Mueller ND, O'Connell C, Ray DK, West PC, Balzer C, Bennett EM, Carpenter SR, Hill J, Monfreda C, Polasky S, Rockström J, Sheehan J, Siebert S, Tilman D, and Zaks DPM (2011) Solutions for a cultivated planet. Nature 478:337-342

Fox D (2007) Back to the no-analog future? Science 316:823-825

Franssen NR, Harris J, Clark SR, Schaefer JF, and Stewart LK (2013) Shared and unique morphological responses of stream fishes to anthropogenic habitat alteration. Proceedings of the Royal Society B: Biological Sciences 280:1751

Freeman MC, Pringle CM, and Jackson CR (2007) Hydrologic connectivity and the contribution of stream headwaters to ecological integrity at regional scales. Journal of the American Water Resources Association 43:5-14 
Fuller PL, Nico LG, and Williams JD (1999) Nonindigenous fishes introduced into inland waters of the United States. American Fisheries Society, Special Publication 27, Bethesda, Maryland

Gido KB, Schaeffer JF, and Falke JA (2009) Convergence of fish communities from the littoral zone of reservoirs. Freshwater Biology 54:1163-1177

Gotelli NJ (2000) Null model analysis of species co-occurrence patterns. Ecology $81: 2606-2621$

Gotelli NJ, and McCabe DJ (2002) Species co-occurrence: a meta-analysis of JM Diamond's assembly rules model. Ecology 83:2091-2096

Gotelli NJ, and Entsminger GL (2010) EcoSim: null models software for ecology. Ver. 7. - Acquired Intelligence Inc. and Kesey-Bear. Jericho, VT 05465

Green DP, Trexler JC, Lorenz JJ, McIvor CC, and Philippi T (2006) Spatial patterns of fish communities along two estuarine gradients in southern Florida. Hydrobiologia 569:387-399

Gunderson LH, and Loftus WF (1993) The Everglades. In: Martin WH, Boyce SG, and Echternacht AC (Eds) Biodiversity of the Southeastern United States: Lowland Terrestrial Communities. John Wiley and Sons, New York, NY, pp. 199-255

Guy CS, Braaten PJ, Herzog DP, Pitlo J and Rogers RS (2009) Sampling warmwater fish in rivers. In: Bonar SA, Hubert WA and Willis DW (Eds) Standard methods for sampling North American freshwater fishes. American Fisheries Society, Bethesda, MD, pp. 59-84

Hobbs RJ, Arico S, Aronson J, Baron JS, Bridgewater P, Cramer VA, and Zobel M (2006) Novel ecosystems: theoretical and management aspects of the new ecological world order. Global ecology and biogeography 15:1-7

Hobbs RJ, Higgs E, and Harris JA (2009) Novel ecosystems: implications for conservation and restoration. Trends in Ecology and Evolution 24:599-605

Hobbs RJ, Higgs ES, and Hall C (2013) Novel ecosystems: intervening in the new ecological world order. Wiley-Blackwell, Chichester, UK

Hoegh-Guldberg O, Mumby PJ, Hooten AJ, Steneck RS, Greenfield P, Gomez E, Harvell CD, Sale PF, Edwards AJ, Caldeira K, Knowlton N, Eakin CM, IglesiasPrieto R, Muthiga N, Bradbury RH, and Hatziolos ME (2007) Coral reefs under rapid climate change and ocean acidification. science 318:1737-1742 
Humborg C, Ittekkot V, Cociasu A, and Bodungen BV (1997) Effect of Danube River dam on Black Sea biogeochemistry and ecosystem structure. Nature 86:385-388

Kiernan JD, Moyle PB, and Crain PK (2012) Restoring native fish assemblages to a regulated California stream using the natural flow regime concept. Ecological Applications 22:472-1482

King RS, Baker ME, Kazyak PF, and Weller DE (2011) How novel is too novel? Stream community thresholds at exceptionally low levels of catchment urbanization. Ecological Applications 21:1659-1678

Kobza RM, Trexler JC, Loftus WF and Perry SA (2004) Community structure of fishes inhabiting aquatic refuges in a threatened Karst wetland and its implications for ecosystem management. Biological Conservation 116:153-165

Kline JL, Loftus WF, Kotun K, Trexler JC, Rehage JS, Lorenz JJ, and Robinson M (2013) Recent Fish Introductions Into Everglades National Park: An Unforeseen Consequence of Water Management? Wetlands, accepted

Legendre P and Anderson MJ (1999) Distance-based redundancy analysis: testing multispecies responses in multifactorial ecological experiments. Ecological Monographs 69:1-24

Legendre P and Gallagher ED (2001) Ecologically meaningful transformations for ordination of species data. Oecologia 129:271-280

Leprieur F, Beauchard O, Blanchet S, Oberdorff T, and Brosse S (2008) Fish invasions in the world's river systems: when natural processes are blurred by human activities. PLoS Biology 6:404-410

Light SS, and Dineen JW (1994) Water control in the Everglades: a historical perspective. In: Davis SM, and Ogden JC (eds) Everglades: The Ecosystem and its restoration. St. Lucie Press, Delray Beach, FL, pp. 47-48

Ligon FK, Dietrich WE, and Trush WJ (1995) Downstream ecological effects of dams. BioScience 45:183-192

Lindenmayer DB, Fischer J, Felton A, Crane M, Michael D, Macgregor C, Montague-Drake R, Manning A, and Hobbs RJ (2008) Novel ecosystems resulting from landscape transformation create dilemmas for modern conservation practice. Conservation Letters 1:29-135

Loftus WF, and Kushlan JA (1987) Freshwater fishes of southern Florida. Bulletin of the Florida State Museum, Biological Sciences 31:147-344 
Loftus WF (2000) Inventory of fishes of Everglades National Park. Florida Scientist 63:27-47

Lugo AE (2009) The emerging era of novel tropical forests. Biotropica 41:589-591

Magoulick DD, and Kobza RM (2003) The role of refugia for fishes during drought: a review and synthesis. Freshwater biology 48:1186-1198

Marchetti MP, Light T, Moyle PB, and Viers JH (2004) Fish invasions in California watersheds: testing hypotheses using landscape patterns. Ecological Applications $14: 507-1525$

Mascaro J, Becklund KK, Hughes RF, and Schnitzer SA (2008) Limited native plant regeneration in novel, exotic-dominated forests on Hawai'i. Forest ecology and management 256:593-606

Matich P and Heithaus MR (2012) Effects of an extreme temperature event on the behavior and age structure of an estuarine top predator Carcharhinus leucas. Marine Ecological Progress Series 447:165-178

Matthews WJ, Gido KB, and Gelwick FP (2004) Fish assemblages of reservoirs, illustrated by Lake Texoma (Oklahoma-Texas, USA) as a representative system. Lake and Reservoir Management 20:219-239

McArdle BH and Anderson MJ (2001) Fitting multivariate models to community data: a comment on distance-based redundancy analysis. Ecology 82:290-297

McKinney ML, and Lockwood JL (1999) Biotic homogenization: a few winners replacing many losers in the next mass extinction. Trends in ecology and evolution $14: 450-453$

McVoy CW, Said WP, Obeysekera J, VanArman JA, and Dreschel TW (2011) Landscapes and Hydrology of the Predrainage Everglades. University Press of Florida, Gainesville, FL

Milton SJ (2003) 'Emerging ecosystems': a washing-stone for ecologists, economists and sociologists? South African Journal of Science 99:404-406

Miranda LE, and Boxrucker J (2009) Warmwater Fish in Large Standing Waters. In: Bonar S, Hubert W, and Willis D (eds) Standard methods for sampling North American freshwater fishes. American Fisheries Society, Bethesda, MD, pp. 29-42

Moody HL (1960) Recaptures of adult largemouth bass from the St. Johns River,Florida. Transactions of the American Fisheries Society 89:295-300 
Moulton SR, Kennen JG, Goldstein RM, and Hambrook JA (2002) Revised protocols for sampling algal, invertebrate, and fish communities as part of the National WaterQuality Assessment Program. U.S. Geological Survey, open-file report 02-150, Reston, VA

Nilsson C, and Berggren K (2000) Alterations of riparian ecosystems caused by river regulation. BioScience 50:783-792

Oliveira EF, Minte-Vera CV, and Goulart E (2005) Structure of fish assemblages along spatial gradients in a deep subtropical reservoir (Itaipu Reservoir, Brazil-Paraguay border) Environmental biology of fishes 72:283-304

Onorato D, Marion KR, and Angus RA (1998) Longitudinal variations in the ichthyofaunal assemblages of the upper Cahaba River: Possible effects of urbanization in a watershed. Journal of Freshwater Ecology 13:139-154

Pandolfi JM, Connolly SR, Marshall DJ, and Cohen AL (2011) Projecting coral reef futures under global warming and ocean acidification. Science 333:418-422

Parkos JJ III, Ruetz CR III, and Trexler JC (2011) Disturbance regime and limits on benefits of refuge use for fishes in a fluctuating hydroscape. Oikos 120:519-1530

Poff NL, Allan JD, Bain MB, Karr JR, Prestegaard KL, Richter BD, Sparks RE and Stromberg JC (1997) The natural flow regime. BioScience 47:769-784

Pope KL, Neumann RM and Bryan SD (2009) Warmwater fish in small standing waters. In: Bonar SA, Hubert WA and Willis DW (Eds) Standard methods for sampling North American freshwater fishes. American Fisheries Society, Bethesda, MD, pp. $13-27$

Pringle CM (2001) Hydrologic connectivity and the management of biological reserves: a global perspective. Ecological Applications 11:981-998

Pringle CM (2003) What is hydrologic connectivity and why is it ecologically mportant? Hydrological Processes 17: 2685-2689

Rabalais NN, Turner RE, and Wiseman WJ Jr (2002) Gulf of Mexico hypoxia, AKA" The dead zone". Annual Review of ecology and Systematics 33:235-263

Rehage JS, and Trexler JC (2006) Assessing the net effect of anthropogenic disturbance on aquatic communities in wetlands: community structure relative to distance from canals. Hydrobiologia 569:359-373 
Rehage JS, and Loftus WF (2007) Seasonal fish community variation in headwater mangrove creeks in the southwestern Everglades: an examination of their role as drydown refuges. Bulletin of Marine Science 80:625-645

Rehage JS, and Boucek RE (2013) Seasonal reassembly: disentangling the effects of regional hydrological disturbance vs. local conditions in an ecotonal fish metacommunity. In Review, Oikos

Rahel FJ (2002) Homogenization of freshwater faunas. Annual Review of Ecology and Systematics 33:291-315

Ricciardi A, and Rasmussen JB (1999) Extinction rates of North American freshwater fauna. Conservation Biology 13:1220-1222

Root TL, and Schneider SH (2006) Conservation and climate change: the challenges ahead. Conservation biology 20:706-708

Rosenberg DM, McCully P, and Pringle CM (2000) Global-scale environmental effects of hydrological alterations: introduction. BioScience 50:746-751

Shafland PL, Gestring KB and Stanford MS (2008) Florida's exotic freshwater fishes. Florida Scientist 71:220-245

Sanders NJ, Gotelli NJ, Heller NE, and Gordon DM (2003) Community disassembly by an invasive species. Proceedings of the National Academy of Sciences 100:24742477

Schofield PJ, Loftus WF, Kobza RM, Cook MI, and Slone DH (2009) Tolerance of nonindigenous cichlid fishes (Cichlasoma urophthalmus, Hemichromis letourneuxi) to low temperature: laboratory and field experiments in south Florida. Biological Invasions 12:2441-2457

Schofield PJ, and Huge DH (2010) Low-temperature tolerance of two non-native fishes (Hoplosternum littorale [Hancock 1828], Cichlasoma bimaculatum [Linnaeus 1758]) established in south Florida USA. Florida Scientist 74: 73-83

Sklar FH, McVoy C, Van Zee R, Gawlik DE, Tarboton K, Rudnick D, Miao S, and Armentano T (2004) The effects of altered hydrology on the Everglades. In: Porter JW, and Porter KG (eds) The Everglades, Florida Bay, and the coral reefs of the Florida Keys: An ecosystem sourcebook. CRC Press, Boca Raton, FL, pp. 39-82

Slawski TM, Veraldi FM, Pescitelli SM, and Pauers MJ (2008) Effects of tributary spatial position, urbanization, and multiple low-head dams on warmwater fish community structure in a Midwestern stream. North American Journal of Fisheries Management 28:1020-1035 
Stone L, and Roberts A (1990) The checkerboard score and species distributions. Oecologia 85:74-7

Trexler JC, Loftus WF, and Perry S (2005) Disturbance frequency and community structure in a twenty-five year intervention study. Oecologia 145:140-152

Walters DM, Leigh DS and Bearden AB (2003) Urbanization, sedimentation, and the homogenization of fish assemblages in the Etowah River Basin, USA. Hydrobiologia 494:5-10

Weaver LA, and Garman GC (1994) Urbanization of a watershed and historical changes in a stream fish assemblage. Transactions of the American Fisheries Society 123:162172

Williams J W, and Jackson ST (2007) Novel climates, no-analog communities, and ecological surprises. Frontiers in Ecology and the Environment 5: 475-482 
APPENDIX A: Summary of sampling effort across the 9 sampling sites by season and hydrologic year.

\begin{tabular}{lcccccc}
\hline & \multicolumn{5}{c}{ Bouts Conducted by Season and Hydrologic Year } \\
\cline { 2 - 7 } Sampling Unit & Wet $_{1}$ & $\begin{array}{c}\text { Early } \\
\text { Dry }\end{array}$ & Late Dry $_{1}$ & Wet $_{2}$ & $\begin{array}{c}\text { Early } \\
\text { Dry }_{2}\end{array}$ & Late Dry $_{2}$ \\
\hline \hline L-29 East & 8 & 10 & 10 & 8 & 8 & 8 \\
L-29 West & 8 & 10 & 10 & 8 & 8 & 8 \\
L-67A $\dagger$ & 5 & 10 & 10 & 8 & 8 & 8 \\
L-31N North $\dagger \dagger$ & 0 & 0 & 10 & 8 & 8 & 0 \\
L-31N South & 8 & 10 & 10 & 8 & 8 & 8 \\
L-31W North & 8 & 10 & 10 & 8 & 8 & 8 \\
L-31W South $\dagger$ & 5 & 10 & 10 & 8 & 8 & 8 \\
C-111 North & 8 & 10 & 10 & 8 & 8 & 8 \\
C-111 South & 8 & 10 & 10 & 8 & 8 & 8 \\
\hline Season Totals: & 58 & 80 & 89 & 72 & 72 & 64 \\
Annual Totals: & & & Yr 1:228 & & & Yr 2: 208 \\
\hline
\end{tabular}

$\dagger$ Bouts reported for L-67A and L-31W South during the wet season of year one are from a pairwise comparison of arrays vs. spheres conducted in Oct., 2010. We only report bouts where spheres were used $(\mathrm{n}=5)$ since the comparison was a paired random design. Thus we exclude the paired array samples from analyses.

$\dagger \dagger \mathrm{L}-31 \mathrm{~N}$ North was deemed not accessible during wet and early dry of hydrologic year 1 of study. New construction in late dry of year 2 prevented access to site as well. 
APPENDIX B. List of the 39 native and 15 non-native species collected in Everglades canals via electrofishing during this study. Values reported are CPUE (\# fish/100m) summed by season and total.

\begin{tabular}{|c|c|c|c|c|c|c|c|c|c|c|c|}
\hline \multirow[b]{2}{*}{ Scientific Name } & \multirow[b]{2}{*}{ Common Name } & \multicolumn{3}{|c|}{ WC Canals } & \multicolumn{3}{|c|}{ MC Canals } & \multicolumn{3}{|c|}{ L Canals } & \multirow[b]{2}{*}{ Total } \\
\hline & & L-67A & $\begin{array}{l}\text { L-29 } \\
\text { West }\end{array}$ & $\begin{array}{c}\text { L-29 } \\
\text { East }\end{array}$ & $\begin{array}{l}\text { L-31W } \\
\text { North }\end{array}$ & $\begin{array}{l}\text { L-31W } \\
\text { South }\end{array}$ & $\begin{array}{l}\text { C-111 } \\
\text { South }\end{array}$ & $\begin{array}{c}\text { L-31N } \\
\text { North }\end{array}$ & $\begin{array}{c}\text { L-31N } \\
\text { South }\end{array}$ & $\begin{array}{l}\text { C-111 } \\
\text { North }\end{array}$ & \\
\hline \multicolumn{12}{|c|}{ Native Taxa (39 Spp.) } \\
\hline Ameiurus natalis & Yellow bullhead & 1 & 37 & 6 & 6 & 0 & 0 & 4 & 0 & 0 & 54 \\
\hline Ameiurus nebulosus & Brown bullhead & 2 & 2 & 4 & 2 & 0 & 0 & 0 & 1 & 1 & 12 \\
\hline Amia calva & Bowfin & 56 & 140 & 68 & 0 & 5 & 14 & 5 & 1 & 2 & 291 \\
\hline Anguilla rostrata & American eel & 2 & 2 & 7 & 5 & 0 & 5 & 2 & 0 & 0 & 23 \\
\hline Elassoma evergladei & Everglades pygmy sunfish & 0 & 0 & 0 & 0 & 1 & 1 & 0 & 0 & 0 & 2 \\
\hline Enneacanthus gloriosus & Bluespotted sunfish & 8 & 28 & 2 & 0 & 6 & 1 & 0 & 0 & 1 & 46 \\
\hline Erimyzon sucetta & Lake chubsucker & 20 & 146 & 28 & 0 & 2 & 0 & 0 & 0 & 1 & 197 \\
\hline Esox niger & Chain pickerel & 10 & 35 & 2 & 0 & 3 & 0 & 0 & 0 & 0 & 50 \\
\hline Etheostoma fusiforme & Swamp darter & 0 & 0 & 2 & 0 & 0 & 0 & 13 & 0 & 1 & 16 \\
\hline Fundulus chrysotus & Golden topminnow & 19 & 44 & 14 & 4 & 12 & 6 & 3 & 0 & 9 & 111 \\
\hline Fundulus confluentus & Marsh killifish & 0 & 0 & 80 & 42 & 2 & 0 & 12 & 0 & 0 & 136 \\
\hline Fundulus grandis & Gulf killifish & 0 & 0 & 0 & 0 & 1 & 0 & 0 & 0 & 0 & 1 \\
\hline Fundulus seminolis & Seminole killifish & 0 & 1 & 11 & 0 & 1 & 2 & 0 & 0 & 0 & 15 \\
\hline Gambusia holbrooki & Mosquitofish & 0 & 27 & 1 & 0 & 0 & 1 & 0 & 2 & 0 & 31 \\
\hline Gobiosoma robustrum & Code goby & 0 & 0 & 0 & 0 & 0 & 1 & 0 & 0 & 0 & 1 \\
\hline Gobiosoma spp. & Unident. goby & 0 & 0 & 0 & 0 & 0 & 0 & 0 & 1 & 0 & 1 \\
\hline
\end{tabular}




\begin{tabular}{|c|c|c|c|c|c|c|c|c|c|c|c|}
\hline Heterandria formosa & Least killifish & 0 & 2 & 0 & 0 & 0 & 0 & 0 & 0 & 0 & 2 \\
\hline Jordanella floridae & Flagfish & 6 & 3 & 357 & 0 & 8 & 1 & 0 & 0 & 0 & 413 \\
\hline Labidesthes sicculus & Brook silverside & 25 & 17 & 18 & 2 & 0 & 4 & 2 & 1 & 0 & 69 \\
\hline Lepisosteus platyrhincus & Florida gar & 826 & 308 & 169 & 216 & 207 & 190 & 41 & 6 & 11 & 1974 \\
\hline Lepomis gulosus & Warmouth & 417 & 857 & 482 & 153 & 178 & 38 & 51 & 23 & 61 & 2260 \\
\hline Lepomis macrochirus & Bluegill & 508 & 617 & 1618 & 155 & 126 & 410 & 57 & 7 & 326 & 3824 \\
\hline Lepomis marginatus & Dollar sunfish & 148 & 358 & 104 & 35 & 159 & 33 & 0 & 0 & 2 & 839 \\
\hline Lepomis microlophus & Redear & 318 & 177 & 235 & 17 & 45 & 118 & 10 & 0 & 59 & 979 \\
\hline Lepomis punctatus & Spotted sunfish & 175 & 787 & 244 & 197 & 491 & 195 & 15 & 3 & 24 & 2131 \\
\hline Lepomis spp. & Sunfishes & 142 & 191 & 241 & 47 & 67 & 62 & 3 & 3 & 41 & 797 \\
\hline Lophogobius cyprinoides & Crested goby & 0 & 0 & 0 & 0 & 0 & 11 & 0 & 0 & 0 & 11 \\
\hline Lucania goodei & Bluefin killifish & 4 & 13 & 3 & 1 & 2 & 1 & 1 & 2 & 5 & 32 \\
\hline Menidia beryllina & Inland silverside & 0 & 2 & 0 & 0 & 0 & 1 & 0 & 0 & 0 & 3 \\
\hline Micropterus salmoides & Largemouth bass & 208 & 214 & 276 & 76 & 125 & 398 & 87 & 136 & 111 & 1631 \\
\hline Mugil cephalus & Striped mullet & 0 & 0 & 2 & 0 & 0 & 3 & 3 & 0 & 0 & 8 \\
\hline Notemigonus crysoleucas & Golden shiner & 19 & 36 & 0 & 0 & 1 & 0 & 0 & 0 & 0 & 56 \\
\hline Notropis maculatus & Taillight shiner & 1 & 1 & 0 & 1 & 0 & 0 & 0 & 0 & 0 & 3 \\
\hline Notropis petersoni & Coastal shiner & 2 & 10 & 5 & 0 & 0 & 0 & 0 & 0 & 0 & 17 \\
\hline Noturus gyrinus & Tadpole madtom & 0 & 0 & 0 & 1 & 0 & 0 & 2 & 1 & 0 & 4 \\
\hline Poecilia latipinna & Sailfin molly & 5 & 10 & 46 & 105 & 33 & 10 & 14 & 1 & 5 & 229 \\
\hline Ameiurus spp. & Unident. bullhead catfish & 0 & 0 & 0 & 3 & 0 & 0 & 0 & 0 & 1 & 4 \\
\hline$\dagger$ Dorosoma cepedianum & $\dagger$ Gizzard shad & 0 & 0 & 2 & 0 & 0 & 0 & 0 & 0 & 0 & 2 \\
\hline$†$ Dorosoma petenense & $\dagger$ Threadfin shad & 1 & 0 & 0 & 0 & 0 & 0 & 0 & 0 & 0 & 1 \\
\hline$\dagger$ Esox americanus & $\dagger$ Redfin pickerel & 0 & 1 & 0 & 0 & 0 & 0 & 0 & 0 & 0 & 1 \\
\hline
\end{tabular}




\begin{tabular}{|c|c|c|c|c|c|c|c|c|c|c|c|}
\hline$\dagger$ Lepisosteus osseus & $\dagger$ Longnose gar & 0 & 0 & 0 & 1 & 0 & 0 & 0 & 0 & 0 & 1 \\
\hline$\dagger$ Pomoxis nigromaculatus & $\dagger$ †lack crappie & 0 & 0 & 0 & 0 & 0 & 0 & 0 & 0 & 1 & 1 \\
\hline & Native Sub Total: & 2923 & 4066 & 4027 & 1107 & 1475 & 1506 & 325 & 188 & 662 & 16279 \\
\hline \multicolumn{12}{|c|}{ Non-native Taxa (15 Spp.) } \\
\hline Belonesox belizanus & Pike killifish & 0 & 0 & 0 & 2 & 6 & 5 & 0 & 0 & 0 & 13 \\
\hline Cichla ocellaris & Butterfly peacock bass & 0 & 1 & 5 & 19 & 13 & 25 & 9 & 6 & 24 & 102 \\
\hline Cichlasoma bimaculatum & Black acara & 0 & 0 & 0 & 15 & 0 & 1 & 0 & 0 & 7 & 23 \\
\hline Cichlasoma managuense & Jaguar Guapote Cichlid & 0 & 0 & 0 & 58 & 1 & 2 & 1 & 7 & 7 & 76 \\
\hline Cichlasoma urophthalmus & Mayan cichlid & 1 & 0 & 40 & 76 & 26 & 91 & 22 & 52 & 24 & 332 \\
\hline Clarias batrachus & Walking catfish & 0 & 0 & 0 & 7 & 3 & 9 & 0 & 0 & 3 & 22 \\
\hline Ctenopharyngodon idella & Grass carp & 2 & 1 & 12 & 0 & 0 & 0 & 1 & 1 & 0 & 17 \\
\hline Hemichromis letourneuxi & Jewel Cichlid & 0 & 0 & 1 & 290 & 64 & 0 & 0 & 0 & 0 & 355 \\
\hline Heros severus & Banded cichlid & 0 & 0 & 0 & 0 & 0 & 0 & 8 & 0 & 0 & 8 \\
\hline Hoplosternum littorale & Armored Catfish & 0 & 1 & 9 & 10 & 0 & 1 & 0 & 0 & 0 & 21 \\
\hline Macrognathus siamensis & Peacock eel & 0 & 0 & 12 & 1 & 22 & 65 & 0 & 0 & 0 & 100 \\
\hline Monopterus albus & Asian Swamp Eel & 0 & 0 & 0 & 18 & 6 & 23 & 0 & 62 & 279 & 388 \\
\hline Oreochromis aureus & Blue tilapia & 1 & 9 & 17 & 30 & 29 & 7 & 0 & 1 & 26 & 120 \\
\hline Pterygoplichthys multiradiatus & Orinoco sailfin catfish & 1 & 5 & 29 & 31 & 4 & 0 & 0 & 1 & 0 & 71 \\
\hline Tilapia mariae & Spotted tilapia & 3 & 1 & 6 & 153 & 104 & 71 & 307 & 225 & 103 & 973 \\
\hline \multirow[t]{3}{*}{ Cichlid spp. } & Unident. cichlid spp. & 0 & 4 & 12 & 80 & 16 & 72 & 2 & 34 & 31 & 251 \\
\hline & Non-native Sub Total: & 8 & 22 & 143 & 790 & 294 & 372 & 350 & 389 & 504 & 2872 \\
\hline & Total: & 2931 & 4088 & 4170 & 1897 & 1769 & 1878 & 675 & 577 & 1166 & 19151 \\
\hline
\end{tabular}

$\dagger$ Denotes range expanded native taxa (5 Spp.) 